\title{
The Adverse Impact of Air Pollution on China's Economic Growth
}

\author{
Daxin Dong *(D), Boyang Xu $(\mathbb{D}$, Ning Shen and Qian He \\ School of Business Administration, Faculty of Business Administration, Southwestern University of Finance \\ and Economics, Chengdu 611130, China; xuboyang@smail.swufe.edu.cn (B.X.); snh@smail.swufe.edu.cn (N.S.); \\ heqian@smail.swufe.edu.cn (Q.H.) \\ * Correspondence: dongdaxin@swufe.edu.cn
}

Citation: Dong, D.; Xu, B.; Shen, N.; $\mathrm{He}, \mathrm{Q}$. The Adverse Impact of Air Pollution on China's Economic Growth. Sustainability 2021, 13, 9056. https://doi.org/10.3390/su13169056

Academic Editor: Weixin Yang, Guanghui Yuan and Yunpeng Yang

Received: 27 June 2021

Accepted: 9 August 2021

Published: 12 August 2021

Publisher's Note: MDPI stays neutral with regard to jurisdictional claims in published maps and institutional affiliations.

Copyright: (C) 2021 by the authors. Licensee MDPI, Basel, Switzerland. This article is an open access article distributed under the terms and conditions of the Creative Commons Attribution (CC BY) license (https:// creativecommons.org/licenses/by/ $4.0 /)$.

\begin{abstract}
This study empirically evaluates the impact of air pollution on China's economic growth, based on a province-level sample for the period 2002-2017. Air pollution is measured by the concentration of fine particulate matter $\left(\mathrm{PM}_{2.5}\right)$, and economic growth is measured by the annual growth rate of gross domestic product (GDP) per capita. A panel data fixed-effects regression model is built, and the instrumental variables estimation method is utilized for quantitative analyses. The study reports a significant negative impact of air pollution on the macroeconomic growth of China. According to our instrumental variables estimation, holding other factors constant, if the concentration of $\mathrm{PM}_{2.5}$ increases by $1 \%$, then the GDP per capita growth rate will decline by 0.05818 percentage points. In addition, it is found that the adverse effect of atmospheric pollution is heterogeneous across different regions. The effect is stronger in the eastern region and in provinces with smaller state-owned enterprise shares, fewer governmental expenditures for public health services, and fewer medical resources. The study results reveal that air pollution poses a substantial threat to the sustainable economic growth of China. Taking actions to abate air pollution will generate great economic benefits, especially for those regions which are heavily damaged by pollution.
\end{abstract}

Keywords: air pollution; $\mathrm{PM}_{2.5}$; economic growth rate; GDP per capita; China

\section{Introduction}

Air pollution is a severe threat to sustainable development in many regions around the world [1-3]. Previous medical and environmental studies have solidly confirmed that air pollution damages human health heavily. Air pollution also has a series of considerable economic consequences. The literature has investigated the influences of air pollution on several aspects of economic activities, including labor productivity [4,5], housing prices [6], wage premiums [7], population mobility [8,9], and the tourism industry [10,11]. However, the impact of air pollution on the growth of the aggregate economy has not been well studied.

It is important to understand the linkage between air pollution and economic growth, as good air quality and economic growth are both essential components of sustainable development. Traditionally, studies on the link between environmental pollution and economic growth have been conducted within the framework of the environmental Kuznets curve (EKC). According to the EKC hypothesis, economic development initially leads to environmental degradation, but, after a certain income level, the degree of environmental pollution reduces. In the EKC model, changes in environmental quality are considered to be a consequence or byproduct of economic growth. However, the relationship between economic growth and pollution is not unidirectional. Given that many economic activities are influenced by the surrounding pollution, pollution likely affects the economic growth rate.

The research objective of this study is to empirically analyze whether and to what extent air pollution exerts impacts on macroeconomic growth in China. This research has an apparently realistic background. China is chosen as the target country of research, 
because China's high economic growth rate and severe air pollution problems are both worthy of attention. Although China had successfully maintained a high gross domestic product (GDP) growth rate for decades, the growth rate gradually diminished during the past decade. It is unsure whether China can hold its leading role as a growth engine of the world. Besides its economic sustainability issue, the environmental sustainability of China is also of interest. The poor air quality in some industrialized and population-dense Chinese cities is widely known. China has taken great efforts to prevent and control air pollution, and an improvement in air quality can be observed in recent years. However, China is currently still on the list of heavily polluted countries. What is the relation between these two phenomena (i.e., declining economic growth rate and severe air pollution in China)? This research will provide helpful insights.

This study offers marginal contributions to the literature in several aspects. (1) This study provides explicit evidence that air pollution has a substantial adverse influence on China's regional economic growth. On the basis of econometric regression estimates, this research offers a quantitative evaluation on the magnitude of air pollution's impact, which enables us to estimate the economic benefits of pollution abatement. (2) Our analysis focuses on the effect of atmospheric pollution on the growth rate of the economy. This feature distinguishes our research from the previous several studies that analyzed the effect of pollution on the level of GDP or GDP per capita. (3) This study also evaluates whether there are heterogeneities in different periods and across different districts. This study obtains a novel finding that the effect of air pollution is not uniform across all districts but dependent on the economic structures and features of the specific regions. (4) The regression analyses in this study confirm that the endogeneity issue of air pollution should be taken into account when using econometric models. Comparing the estimation result of a standard panel data fixed-effects estimation with that of an instrumental variables estimation shows that, if we incorrectly ignore the endogeneity of air pollution, the adverse impact of air pollution will be underestimated.

The remainder of this article is organized as follows. Section 2 develops the research hypothesis and reviews the existing literature. The empirical model and data are presented in Section 3. Section 4 provides the detailed estimation results. Finally, Section 5 discusses the research findings, concludes the paper, and offers information for future research directions.

\section{Hypothesis Development and Literature Review}

\subsection{Hypothesis Development}

It is widely known that air pollution poses public health risks. For instance, air pollution causes a higher incidence of many illnesses and unhealthy symptoms, including attention deficits [12,13], cardiovascular problems [14], cognitive impairment [15,16], headaches [17], irritability [18], mental depression [19], respiratory diseases [20,21], and so on. Air pollution results in a substantial global burden of diseases, higher morbidity, and increased mortality $[22,23]$. The health damages created by air pollution have severe economic consequences. In particular, previous studies have reported that air pollution reduces productivity, causes a loss of human capital, and strongly depresses some industries which are dependent on a clean environment.

As the health status of laborers becomes worse as a result of atmospheric pollution, productivity in economic activities declines. Laborers in poor health cannot work in a sufficiently efficient way. The previous labor economics literature has confirmed that air pollution has largely reduced the labor productivity in different industries across the world [4,5]. In addition, a recent study by Zhao and Yuan [24] reported that air pollution has an inhibitory effect on the total factor productivity (TFP) in China. As labor productivity and TFP are key determinants of economic growth [25-28], the damage of air pollution on productivity indicates that economic growth is harmed.

Air pollution also causes a loss of human capital, as some high-skilled laborers may choose to leave polluted areas and human cognitive abilities are damaged by pollution. 
The environmental literature has found that the degree of perception and concern about atmospheric pollution rises with the increasing education level of individuals [29-31]. This implies that highly skilled laborers, such as scientists and technicians, who are usually well-educated on average, may be significantly responsive to the air pollution issue. Some of these individuals are likely to leave polluted regions, as previous studies have detected that air pollution affects people's mobility and residence decisions $[6,8,9]$. The leaving of laborers with high education levels results in a loss of human capital in the society. Moreover, the medical literature has identified that air pollution causes a decline in human cognitive abilities $[15,16]$. In consequence, pollution has an implicit damage on human capital in industries requiring high cognitive performance. For instance, Luo et al. [32] reported that air pollution in China reduces inventors' annual new patent output, reflecting a decrease in innovative abilities of researchers. Given the importance of human capital in sustainable economic growth [33-35], a loss of human capital induced by atmospheric pollution implies that economic growth is reduced.

Furthermore, air pollution directly depresses the development of certain industries that substantially rely on a clean environment. A particularly notable example is tourism. Given the fact that good environmental quality is an indispensable characteristic of attractive tourist destinations [36-40], tourism is heavily hurt by air pollution [10,11,41]. Air pollution inhibits sightseeing activities, damages the tourist experience, poses potential health risks, and, thus, reduces the competitiveness of a tourism destination [37-39,42-44]. The number of tourist arrivals and amount of tourism revenue both decline in air-polluted regions $[45,46]$, as many tourists are unwilling to visit polluted areas. Potential tourists have explicitly been aware of and concerned with the air pollution in China [10,47]. The tourists' perception of air pollution has apparently reduced their willingness to visit China and the trip satisfaction [48-50]. As tourism is an economic growth engine in numerous districts [51,52], air pollution depresses economic growth through its damage to tourism. In addition to tourism, the sustainable development of agriculture is also severely hindered by air pollution [53-55], as crop yields and the diversification of wild species are adversely impacted.

In short, air pollution reduces economic productivity, causes human capital loss, and directly hampers the development of several environment-dependent industries. Although people might partially mitigate the damage of air pollution by taking some protective actions (e.g., building better infrastructure to prevent the indoor intrusion of outdoor pollution, using more air purifiers and masks, and being more informed to avoid staying in severely polluted areas and periods), these actions come at the cost of economic resources and daily inconvenience, while the harmfulness of pollution can hardly be eliminated completely. On the basis of the above analyses, it is reasonable to conjecture that air pollution impedes economic growth. Thus, the research hypothesis in this study was established as follows:

Hypothesis 1. Air pollution has a negative impact on economic growth.

\subsection{Literature Review}

Many previous studies, such as Atici [56], Dinda [57], Dong et al. [58], Farhani et al. [59], Gokmenoglu et al. [60], Luo et al. [61], Millimet et al. [62], and Zhang et al. [63], have analyzed the environmental Kuznets curve, which discusses the variations of pollutant emissions and environmental quality at different economic development states, reflected by the levels of per capita income. However, the impact of pollution on economic growth has not been sufficiently investigated in the literature.

Some studies have analyzed the influence of carbon dioxide $\left(\mathrm{CO}_{2}\right)$ emissions on economic growth; however, the findings were inconclusive. For instance, Abdouli and Hammami [64] investigated the situation in 17 Middle Eastern and North African (MENA) countries, Omri et al. [65] explored a global panel of 54 countries, and Omri et al. [66] analyzed 12 MENA countries. They all reported a significant negative impact of $\mathrm{CO}_{2}$ 
emissions on economic growth. Differing from their findings, the study by Ghosh [67] focused on India and reported that no statistically significant long-term effect of carbon emissions on economic growth was detected. Similar conclusions were obtained by Ozturk and Acaravci [68] for Turkey, Zhang and Cheng [69] for China, and so on. Some studies have reported a positive effect of carbon emissions on economic growth. For example, Azam et al. [70] found that the impact of $\mathrm{CO}_{2}$ emissions on economic growth was positive in the US, China, and Japan, although it was negative in India. Ahmad and Du [71] reported a positive influence of carbon emissions on economic growth in Iran. Muhammad [72] found that carbon emissions stimulated economic growth in developed and MENA countries.

It is notable that the scale of $\mathrm{CO}_{2}$ emissions may not perfectly reflect the degree of ambient air pollution affecting human lives, as the actual concentration of air pollutants is greatly shaped by meteorological and geographical conditions. The volume of carbon emissions is tightly relevant to the intensity of energy use and the degree of energy efficiency in one region but may not be a satisfactory indicator of the density of pollutants in ambient air.

A few studies have explicitly used the measured density of atmospheric pollutants to denote the degree of air pollution. Dechezleprêtre et al. [73] took a sample of European regions over the period 2000-2015 and reported that a $1 \mu \mathrm{g} / \mathrm{m}^{3}$ increase in the density of fine particulate matter $\left(\mathrm{PM}_{2.5}\right)$ caused a $0.8 \%$ reduction in real GDP. Sinha [74] reported that nitrogen dioxide $\left(\mathrm{NO}_{2}\right)$ and sulfur dioxide $\left(\mathrm{SO}_{2}\right)$ emissions significantly harmed the regional income levels for a panel of 139 Indian cities during the period 2001-2013. Hao et al. [75] estimated the impact of $\mathrm{PM}_{2.5}$ pollution on the level of GDP per capita in Chinese cities between 2013 and 2015. They reported a significant negative impact: a 1\% increase in $\mathrm{PM}_{2.5}$ concentration was found to trigger the GDP per capita to decline by around $0.3-0.8 \%$, depending on the model specifications used. Zhao and Sing [76] further reported that dust and $\mathrm{SO}_{2}$ emissions in neighboring cities generated a negative spillover effect on the GDP of local Chinese cities. On the other hand, Gan et al. [77] reported that the spatial spillover effect of atmospheric pollution is positive. Jiang et al. [78] found no significant impact of $\mathrm{SO}_{2}$ emissions on local GDP but reported a positive impact of air pollution in neighboring cities, based on the data for 28 cities in China during 20062015. These six studies provided findings that air pollution affects the level of economic development. However, we cannot simply say that the impact of air pollution on economic growth has been confirmed by these above-mentioned studies. It should be noted that the dependent variable used in these studies was the level of GDP or GDP per capita. Thus, the estimated regression coefficient of air pollution essentially evaluated its contemporaneous impact on economic scale, rather than the long-run effect on economic growth [73]. Taking the economic growth rate as the dependent variable in the regression equation is more consistent with that used in the economic growth literature (e.g., [79-85]). In our study, we use this kind of model setup and examine the effect of air pollution on the regional economic growth rate in Chinese provinces.

In brief, the existing literature has several gaps. (1) Based on the prior studies, although it is not difficult to infer intuitively that air pollution might negatively affect economic growth, there is not enough empirical evidence to directly verify this intuition. Particularly, we lack detailed studies to quantify the effect of air pollution. (2) As mentioned before, several previous studies used the level of GDP (per capita) as the dependent variable in regression models. However, the theory of economic growth pointed out the importance of inspecting the growth rate of GDP (per capita). The several above-mentioned studies did not consider this. (3) Different districts may own disparate macroeconomic structures and features, which influence the magnitude of air pollution's impact. The existing literature did not pay sufficient attention to the heterogeneous effects of air pollution.

\subsection{Key Feature of This Study}

The key feature of this study, which differentiates ours from the previous research, is that we use the GDP (per capita) growth rate, instead of the GDP (per capita), as the 
dependent variable in the econometric regression model. This point is crucial, as models using different dependent variables tell different stories. To clarify this, let us consider the following two simplified models:

$$
\begin{array}{ll}
\text { Model I: } & G D P_{t}=a_{0}+a_{1} \times \text { AirPollution }_{t} \quad\left(a_{0}>0, a_{1}<0\right), \\
\text { Model II: } \quad \begin{array}{l}
G D P G r o w t h \text { Rate }_{t}=b_{0}+b_{1} \times \text { AirPollution }_{t} \\
\text { GDd } \quad
\end{array} \quad\left(b_{0}>0, b_{1}<0\right)
\end{array}
$$

where $G D P_{t}$ refers to the scale of GDP in period $t, G D P G r o w t h R a t e_{t}$ is the growth rate of the GDP, and AirPollution ${ }_{t}$ is the degree of air pollution which negatively affects GDP or its growth rate.

First, we consider the scenario described by Model I. In this scenario, a change in the degree of air pollution alters the scale of the GDP but not the growth rate. This scenario has at least two important implications regarding economic growth. (1) Holding other things constant, in order to continuously increase the GDP, the region has to reduce its air pollution endlessly. If air quality reaches a level that the region can hardly further improve, the growth of the GDP will stop. (2) Another important implication is that the GDP in regions with bad air quality can quickly catch up with that in regions with good air quality by reducing air pollution. This is because variations in air pollution cause corresponding shifts in the scale of GDP, as reflected by Model I. We use Figure 1 to illustrate these two implications visually.

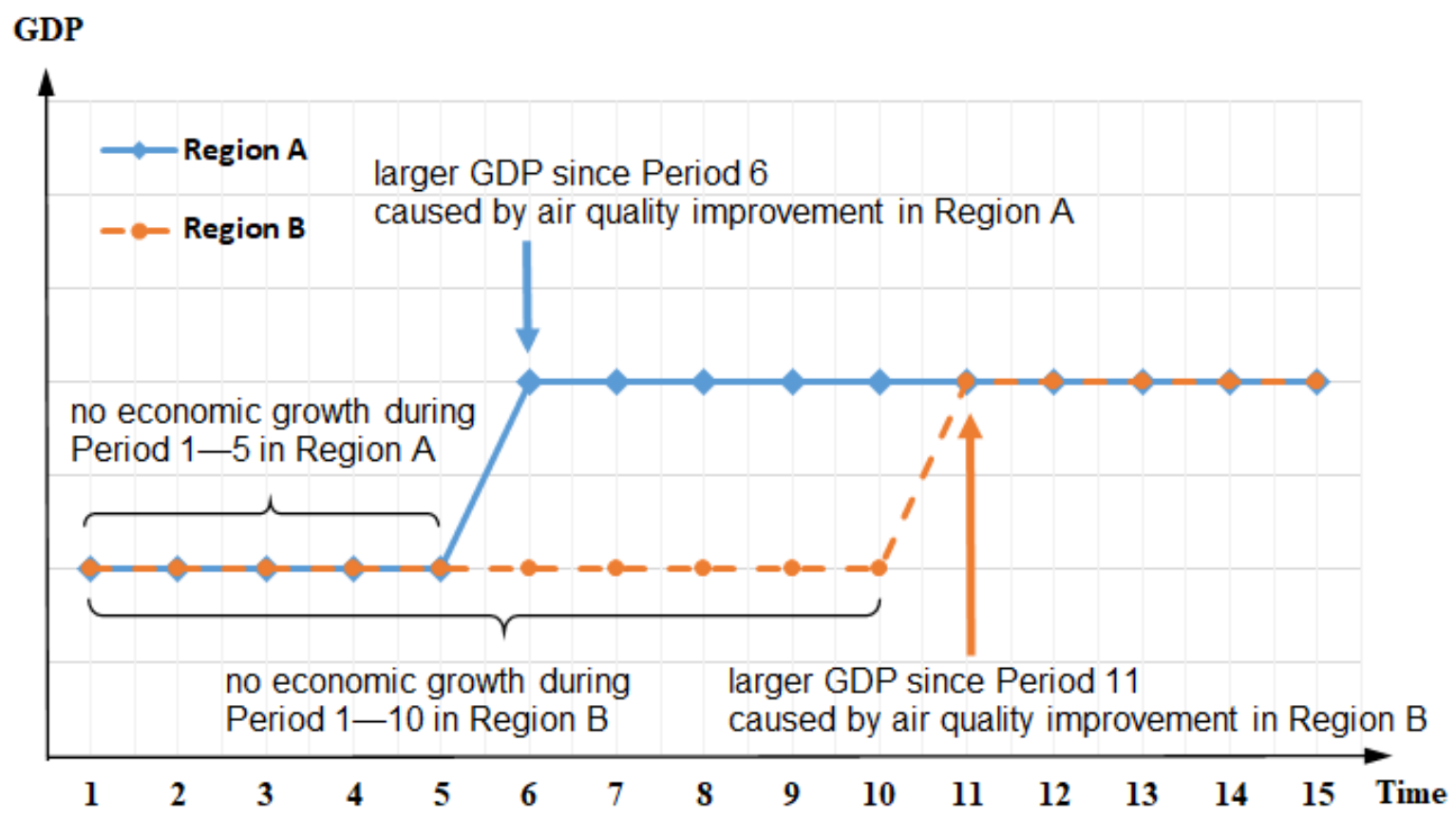

Figure 1. An illustrative case of a world in which air pollution affects the GDP scale. Abbreviation: GDP (gross domestic product).

Suppose that there are two regions (A and B) and fifteen periods. These two regions are identical in the beginning, and Regions A and B improve their air quality in Periods 6 and 11, respectively. As shown in the figure, these two regions are totally the same and unchanged in the first five periods. In Period 6, Region A reduces its air pollution and maintains improved air quality afterwards. Thus, from Period 6, the GDP size of Region A is constant and larger than that in Periods 1-5. The air quality in Region B is not improved until Period 11. From Period 11, Region B has good air quality, analogous 
to that in Region A. Therefore, the GDP of Region B catches up with Region A in Period 11 and keeps a constant scale afterwards. Overall, in the world of Model I, a reduction in air pollution contemporaneously expands the GDP scale, but sequential growth of the economy is not guaranteed.

Next, we consider the scenario described by Model II. In this scenario, a change in the degree of air pollution alters not only the scale of the GDP but also its development trend. This circumstance has two important implications regarding economic growth. (1) Holding other things constant, in order to continuously increase the GDP, the region should maintain air quality at a satisfactory level, such that the economic growth rate is positive. Different from the world of Model I, the region does not need to reduce air pollution endlessly. Even though the local air quality cannot be further improved in the future, the GDP will still grow. (2) As air pollution changes the economic growth rate, which has an accumulative effect, the gap of GDP scale between regions with different air qualities will expand increasingly over time. This indicates that regions which reduce air pollution earlier can establish an advantage in GDP expansion, compared to other regions which reduce their air pollution later. The earlier the regions improve their air quality, the better. The GDP of regions with relatively severe air pollution cannot easily catch up with the regions which reduce pollution earlier. We use Figure 2 as a visual example of these two implications.

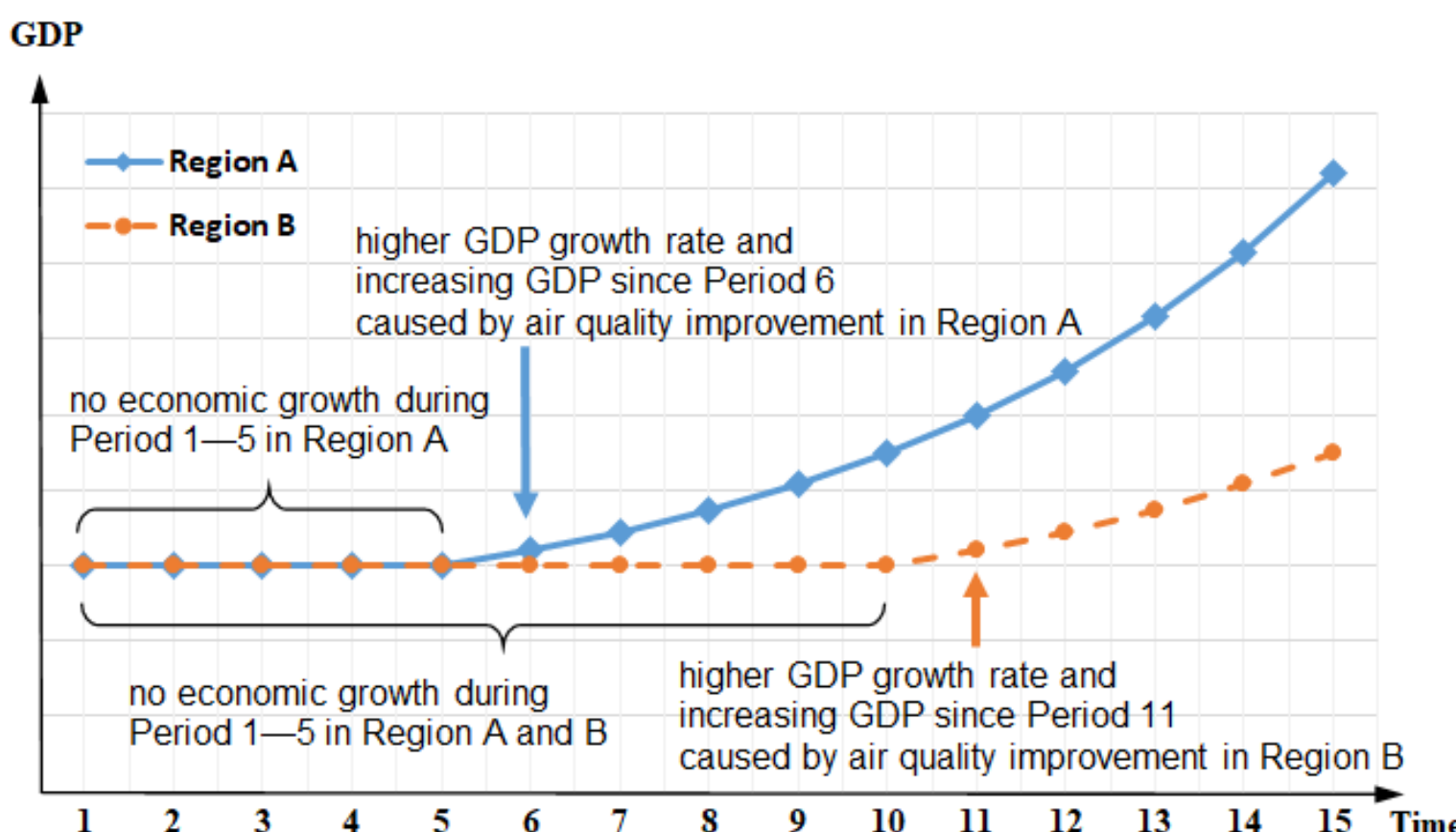

Figure 2. An illustrative case of a world in which air pollution affects the GDP growth rate. Abbreviation: GDP (gross domestic product).

We assume that there are two regions (A and $\mathrm{B}$ ) and fifteen periods. The two regions are completely identical in the beginning. Region A and B ameliorate their air quality in Periods 6 and 11, respectively. As demonstrated by the graph, during Periods 1-5, the situations in the two regions are the same and invariant. In Period 6, Region A improves its air quality and maintains better air quality afterwards. Hence, from Period 6, Region A has a higher GDP growth rate and its GDP scale increasingly expands. The air quality in Region B is not made better until Period 11. From Period 11, Region B also has good air quality, similar to that in Region A. In consequence, during Periods 11-15, the GDP growth 
rate of Region B is as high as that of Region A. However, because the GDP scale of Region A is significantly larger than Region B, the same GDP growth rate in two regions implies that Region B cannot catch up with Region A, in terms of GDP scale. Overall, in the world of Model II, a reduction in air pollution not only enlarges the GDP scale, but also has a persistent impact on future economic growth.

The discussion above makes it clear that it is important to distinguish whether air pollution affects GDP scale or GDP growth rate. As the previous literature has analyzed the impact of air pollution on the Chinese GDP [75-78], we focus on the influence of pollution on GDP growth rate in this study.

\section{Model and Data}

\subsection{Model}

Our research sample has a panel data structure with two dimensions: the time and the cross-region dimension. Thus, our empirical analyses utilize a classical regression model with two-way fixed-effects, which is standard in panel data econometrics. The model is formulated by the equation

$$
\text { Growth }_{i t}=\alpha \text { AirPollution }_{i t}+X_{i t} \beta+s_{i}+v_{t}+\varepsilon_{i t},
$$

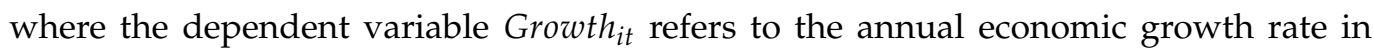
province $i$ in year $t$. The core explanatory variable of interest is AirPollution A $_{i t}$, the level of air pollution. The vector $X_{i t}$ is a vector of control variables; $s_{i}$ and $v_{t}$ refer to the provinceand time-fixed effects, respectively; and $\varepsilon_{i t}$ is the error term. The coefficients $\alpha$ and $\beta$ will be estimated using regression methods. Based on these coefficients, we can evaluate the effects of different explanatory variables. In particular, we concentrate on the impact of air pollution, captured by the coefficient $\alpha$.

\subsection{Variable}

\subsubsection{Dependent Variable}

This study intends to assess the influence of atmospheric pollution on economic growth. Thus, following the empirical literature on economic growth, such as the studies of Alesina et al. [79], Chikalipah and Makina [80], Davis and Hopkins [81], Feeny et al. [82], Hermes and Lensink [83], Njikam [84], and Rioja and Valev [85], we take the annual growth rate of the real GDP per capita as the dependent variable. In the robustness analysis section, we consider the growth rate of the GDP as an alternative dependent variable.

It is notable that the dependent variable is the growth rate of GDP per capita, not the level of GDP per capita. This distinguishes our model setup from that of Dechezleprêtre et al. [73], Gan et al. [77], Hao et al. [75], Jiang et al. [78], Sinha [74], and Zhao and Sing [76], who took the logarithmic value of GDP or GDP per capita as the dependent variable. From a long-run perspective, it is even more important to examine the influence of air pollution on the growth potential of an economy, compared to its effect on the contemporary level of economic development. Therefore, focusing on the rate of growth is prevalent in the economic growth literature. We follow this tradition.

\subsubsection{Core Explanatory Variable of Interest}

The core explanatory variable in this study is AirPollution, the level of air pollution. Previous studies have verified that $\mathrm{PM}_{2.5}$ is one of the most crucial atmospheric pollutants in Chinese regions [86,87]. Therefore, we use the annual population-weighted average concentration of $\mathrm{PM}_{2.5}\left(\mu \mathrm{g} / \mathrm{m}^{3}\right)$ in each Chinese province to denote the degree of pollution. To address the scaling problem, the logarithmic value of $\mathrm{PM}_{2.5}$ concentration is used as the explanatory variable. Thus, the changes in air pollution are expressed in percentage points.

The sample average $\mathrm{PM}_{2.5}$ concentration is $45.993 \mu \mathrm{g} / \mathrm{m}^{3}$. This pollution level is substantially higher than the desirable level of $10 \mu \mathrm{g} / \mathrm{m}^{3}$ as suggested by the World Health Organization (WHO)'s Air Quality Guidelines. The standard deviation of pollution level is $18.029 \mu \mathrm{g} / \mathrm{m}^{3}$, indicating apparent differences among different provinces. The minimum 
value is $5.7 \mu \mathrm{g} / \mathrm{m}^{3}$, observed in Tibet in 2003 . The maximum is $88.8 \mu \mathrm{g} / \mathrm{m}^{3}$, recorded in Beijing in 2006.

We use Figure 3 to briefly demonstrate the distribution of $\mathrm{PM}_{2.5}$ pollution among different provinces in Mainland China. We calculate the average $\mathrm{PM}_{2.5}$ concentration during the sample period 2002-2017 for every province and use different colors in the graph to indicate different severities of pollution. As shown in the figure, two areas have the highest degree of pollution, with average $\mathrm{PM}_{2.5}$ concentration exceeding $60 \mu \mathrm{g} / \mathrm{m}^{3}$. One area consists of several provinces around Beijing City, which is located in North China and features high population density; the other area is Xinjiang, which is located in the most northwest part of China and contains some vast deserts. The area with the best air quality, with average $\mathrm{PM}_{2.5}$ concentration below $20 \mu \mathrm{g} / \mathrm{m}^{3}$, includes three provinces located in Southwest and South China. These three provinces are Tibet, Yunnan, and Hainan, which are all famous for their beautiful natural sceneries.

\subsubsection{Control Variable}

There are 11 important control variables included in the vector X: Education, CapitalFormation, FinancialDevelopment, FinancialOpenness, TradeOpenness, Road, GovernmentSize, Population, GDPPerCapita, IndustrialStructure, and SolidWasteEmission.

Education is an indicator of the average education level of laborers. Human capital, majorly accumulated through education and training, is crucial for sustainable economic growth [88-91]. Thus, it is expected that education level has a positive effect on economic growth. We use the average value of schooling years of laborers as a proxy for the level of education.

CapitalFormation refers to the value of the capital formation rate, namely the ratio of fixed capital investment to GDP. As capital is a kind of indispensable production input, we expect that capital formation boosts economic growth in China. Previous studies, such as those of Adams [92], Bal et al. [93], and Uneze [94], have also reported a positive effect of capital formation on economic growth in different countries.

FinancialDevelopment is an indicator for financial development, indexed by the ratio of bank credits to GDP. Although some studies have reported a positive impact of financial development on economic growth, many researchers have found that the impact may be non-linear or dependent on the specific economic environment $[85,95-97]$. Thus, we do not have a specific expectation for the sign of this variable's coefficient.

FinancialOpenness is an indicator of financial openness. We use the foreign direct investment (FDI) per capita (CNY, in constant 2010 price) as a proxy for this variable. The literature has reported inconsistent findings about the impact of financial openness [84,98]. Almfraji and Almsafir [99] conducted a literature review and found that the estimated impact of FDI was positive in some studies but was negative or null in other research.

TradeOpenness is an indicator of trade openness, which is measured by the ratio of international trade volume to GDP. Given the fact that China has a great volume of international trade with many countries, trade openness may affect China's economic growth and, thus, should be considered as a control variable. The previous literature has reported mixed evidence about the impact of trade openness on GDP growth [100-103].

Road is an indicator of the abundance of the transportation infrastructure, proxied by the road length $(\mathrm{km})$ per area $\left(\mathrm{km}^{2}\right)$. It has been widely confirmed that infrastructure plays an beneficial role in regional economic development [104-107]. We expect that the estimated coefficient of this variable will have a positive sign. 


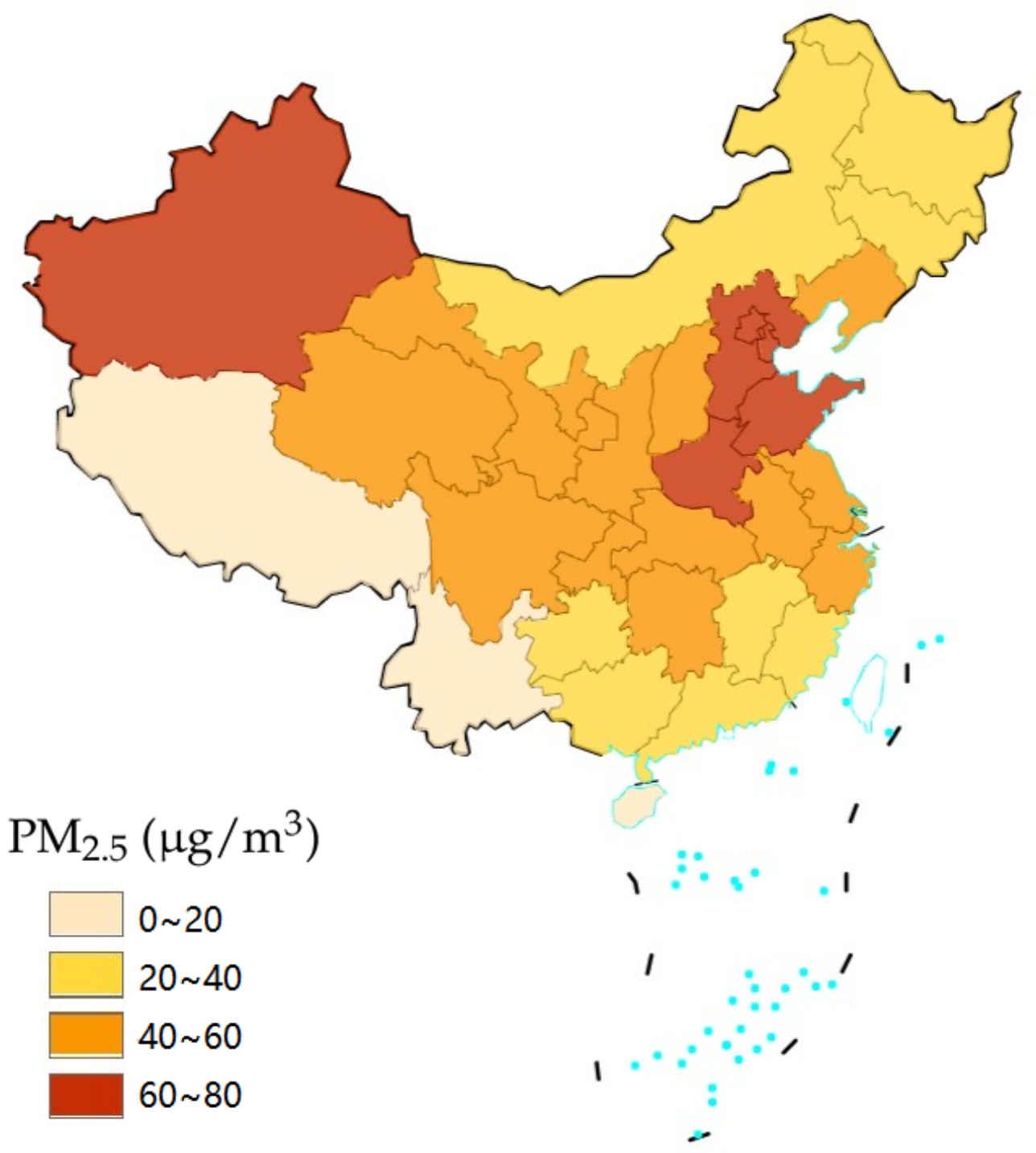

Figure 3. Average $\mathrm{PM}_{2.5}$ concentration (2002-2017) in different provinces of Mainland China. Abbreviation: $\mathrm{PM}_{2.5}$ (fine particulate matter). Data source of $\mathrm{PM}_{2.5}$ concentration: Atmospheric Composition Analysis Group at Dalhousie University, Canada.

GovernmentSize refers to government size, measured by the ratio of fiscal expenditures to local GDP. This variable captures the role of the local government in regional economic growth. According to the literature, the impact of government size on economic growth is not clear-cut [108]. While some studies, such as those of Afonso and Furceri [109] and DiPeitro and Anoruo [110], have reported a negative impact, Asimakopoulos and Karavias [111] and Chiou-Wei et al. [112] reported a non-linear relationship. Given the importance of government in making macroeconomic and development policies in China, it is possible that government size has a positive influence on China's economic growth.

Population is the size of population within the province. Population change has important impacts on economic growth $[113,114]$. On the one hand, the agglomeration effects arising from a large population size may promote economic growth. On the other hand, numerically, population growth reduces the value of GDP per capita, if the scale of GDP cannot expand faster than the population. Thus, the effect of population on economic growth is ambiguous.

In addition, we control the variables describing the general economic status of each region. Two variables are included as control variables: GDPPerCapita, the logarithmic 
value of real GDP per capita (CNY, in constant 2010 price), and IndustrialStructure, the industrial structure proxied by the share of non-agricultural value added in GDP.

Finally, we consider that other types of pollutants may also affect economic growth. In the model, we control the pollution of solid wastes by using the variable SolidWasteEmission, which measures the solid waste emissions (tons) per capita.

\subsection{Data}

The air pollution data were derived from the Atmospheric Composition Analysis Group at Dalhousie University, Canada. The data file is available at the web page: http:/ / fizz.phys.dal. $\mathrm{ca} / \sim a t m o s / \mathrm{martin} /$ ?page_id=140, accessed on 1 March 2021. van Donkelaar et al. $[115,116]$ and Hammer et al. [117] provided details about the methodology used to calculate the value of annual average $\mathrm{PM}_{2.5}$ concentration within an area. The data of dependent variables and control variables were obtained from the database of the EPS China Data, accessible at its website: http:/ / www.epschinadata.com, accessed on 1 March 2021. The EPS platform has collected and stored numerous data from different statistical reports and yearbooks offered by the official statistical departments.

The research sample covers all 31 provinces in Mainland China. Based on the data availability, the sample spans a time interval of 16 years, between 2002 and 2017. There are 496 observations in total. Table 1 reports the definitions and summary statistics of variables employed in this study.

Table 1. Summary statistics.

\begin{tabular}{|c|c|c|c|c|c|c|}
\hline Variable & Definition & Obs & Mean & SD & Min & Max \\
\hline Growth & Annual growth rate (\%) of real GDP per capita & 496 & 10.253 & 2.951 & -2.300 & 23.600 \\
\hline AirPollution & $\begin{array}{l}\text { Air pollution, measured by logarithmic value of the } \\
\text { annual population-weighted average } \mathrm{PM}_{2.5} \\
\text { concentration }\left(\mu \mathrm{g} / \mathrm{m}^{3}\right)\end{array}$ & 496 & 3.719 & 0.533 & 1.740 & 4.486 \\
\hline Education & $\begin{array}{l}\text { Education level, measured by the average schooling } \\
\text { years of laborers }\end{array}$ & 496 & 8.495 & 1.225 & 3.738 & 12.503 \\
\hline CapitalFormation & $\begin{array}{l}\text { Capital formation rate, measured by the ratio of fixed } \\
\text { capital investment to GDP }\end{array}$ & 496 & 0.646 & 0.248 & 0.237 & 1.507 \\
\hline FinancialDevelopment & $\begin{array}{l}\text { Financial development, measured by the ratio of bank } \\
\text { credits to GDP }\end{array}$ & 496 & 1.639 & 0.719 & 0.751 & 5.587 \\
\hline FinancialOpenness & $\begin{array}{l}\text { Financial openness, measured by foreign direct } \\
\text { investment per capita (CNY, in constant } 2010 \text { price) }\end{array}$ & 496 & 1.661 & 2.660 & 0.063 & 20.469 \\
\hline TradeOpenness & $\begin{array}{l}\text { Trade openness, measured by the ratio of international } \\
\text { trade volume to GDP }\end{array}$ & 496 & 0.298 & 0.349 & 0.012 & 1.668 \\
\hline Road & $\begin{array}{l}\text { Transport infrastructure, measured by road length }(\mathrm{km}) \\
\text { per area }\left(\mathrm{km}^{2}\right)\end{array}$ & 496 & 7.285 & 4.850 & 0.324 & 21.146 \\
\hline GovernmentSize & $\begin{array}{l}\text { Government size, measured by the ratio of fiscal } \\
\text { expenditures to GDP }\end{array}$ & 496 & 0.232 & 0.180 & 0.079 & 1.379 \\
\hline Population & Logarithmic value of population (10,000 persons) & 496 & 8.076 & 0.863 & 5.576 & 9.306 \\
\hline GDPPerCapita & $\begin{array}{l}\text { Logarithmic value of GDP per capita (CNY, in constant } \\
2010 \text { price) }\end{array}$ & 496 & 10.107 & 0.674 & 8.407 & 11.661 \\
\hline IndustrialStructure & $\begin{array}{l}\text { Industrial structure, measured by the share }(\%) \text { of } \\
\text { non-agricultural value added in GDP }\end{array}$ & 496 & 88.053 & 6.272 & 62.100 & 99.638 \\
\hline SolidWasteEmission & Solid waste emissions (tons) per capita & 496 & 2.079 & 3.022 & 0.017 & 25.267 \\
\hline
\end{tabular}

Abbreviations: CNY (Chinese Yuan), GDP (gross domestic product), Max (maximum), Min (minimum), Obs (observations), PM $_{2.5}$ (fine particulate matter), SD (standard deviation).

\section{Results}

In this section, we report the estimated impact of air pollution on GDP growth. In Section 4.1, the estimation results of the fixed-effects model are reported. In Section 4.2, we deal with the endogeneity issue by utilizing the instrumental variables approach, which provides more reliable estimates. In Section 4.3, we explore the heterogeneous effects of air pollution in different periods and regions. 


\subsection{Results of Fixed-Effects Estimation}

\subsubsection{Baseline}

The estimation result of Equation (1) is shown in column (i) of Table 2. The coefficient of AirPollution was -2.108 and statistically significant at the $5 \%$ level. In other words, it was found that air pollution significantly harmed economic growth. According to the estimated coefficient, holding other factors constant, if the concentration of $\mathrm{PM}_{2.5}$ rises by $1 \%$, then the annual growth rate of GDP per capita will decline by 0.02108 percentage points.

Some of the control variables also help explain economic growth in China. As expected, the level of education (Education) had a positive coefficient, although it was not statistically significant. Capital investment (CapitalFormation) significantly promoted economic growth. This reflects the importance of investment in China's rapid economic expansion. The expansion of bank credits (FinancialDevelopment) demonstrated a significant negative effect. The degree of financial openness (FinancialOpenness) had a significant positive effect. This supports the opinion that FDI benefits China's economic development. Trade openness (TradeOpenness) did not have a significant influence on economic growth. Transportation infrastructure (Road) had a positive coefficient; however, this coefficient was not statistically significant. Government size (GovernmentSize) demonstrated a significant positive impact, reflecting the active role of government in the Chinese economy. Population size (Population) has a significant negative effect, indicating that the economies with larger population scales tend to grow more slowly. GDP per capita (GDPPerCapita) had a negative coefficient, indicating the existence of economic convergence among different regions; namely, economies with relatively low per capita incomes tend to grow at faster rates than relatively rich economies. The proportion of non-agricultural value added in GDP (IndustrialStructure) had a significant positive correlation with economic growth rate, in line with the phenomenon that economic growth is accompanied by the process of industrial structure updating. The coefficient of solid waste emissions (SolidWasteEmission) was significantly negative, implying that solid waste pollution also harms economic growth.

\subsubsection{Robustness Check}

In this subsection, we check whether the estimated significant negative coefficient of AirPollution in column (i) was robust to the selection of economic growth indicator, existence of possible outliers, and measurement of air pollution.

Previously, we used the annual growth rate of real GDP per capita to measure the economic growth. Here, we used the growth rate of real GDP as the dependent variable in Equation (1) and re-estimated the coefficients. The results are presented in column (ii). The estimated coefficient of AirPollution was -1.972 and was still statistically significant at the $10 \%$ level. The coefficients of control variables were also similar to that in column (i).

In order to abate the disturbances from possible outliers, we winsorized the observations with the top $2.5 \%$ or bottom $2.5 \%$ values of economic growth rate. The estimation results for this winsorized sample are reported in column (iii). It is shown that this study's main finding about the adverse impact of air pollution held. The coefficient of AirPollution was -1.505 and statistically significant at the $10 \%$ level.

In previous regressions, we used the concentration of $\mathrm{PM}_{2.5}$ as the indicator of atmospheric pollution. Here, we examined whether our study result is sensitive to the selection of pollution indicator. Given that $\mathrm{SO}_{2}$ is also a crucial pollutant in China, we used the $\mathrm{SO}_{2}$ concentration to represent the severity of air pollution. The $\mathrm{SO}_{2}$ data were downloaded from the platform of EPS China Data (http: / / www.epschinadata.com, accessed on 1 March 2021). As the governmental department of environmental protection only reported $\mathrm{SO}_{2}$ concentration for a few cities, we failed to calculate the annual average value for the whole province. Thus, we used the value of $\mathrm{SO}_{2}$ concentration in the capital city of a province to proxy the degree of pollution in that province, considering that the capital city is typically also the economic center and the city with the most population in the corresponding province. We reported the estimation result in column (iv). The estimated coefficient of AirPollution was -1.375 and significant at the $1 \%$ level. 
Table 2. Estimated impact of air pollution on economic growth rate based on fixed-effects estimation.

\begin{tabular}{|c|c|c|c|c|}
\hline \multirow{3}{*}{ Variable } & \multirow[b]{2}{*}{ Baseline } & \multicolumn{3}{|c|}{ Robustness Analysis } \\
\hline & & $y=$ GDP Growth Rate & $\begin{array}{c}\text { Based on Winsorized } \\
\text { Sample }\end{array}$ & $\begin{array}{c}\text { AirPollution }=\mathrm{SO}_{2} \\
\text { Concentration }\end{array}$ \\
\hline & (i) & (ii) & (iii) & (iv) \\
\hline AirPollution & $\begin{array}{l}-2.108^{* *} \\
{[0.953]}\end{array}$ & $\begin{array}{l}-1.972 * \\
{[0.994]}\end{array}$ & $\begin{array}{l}-1.505^{*} \\
{[0.783]}\end{array}$ & $\begin{array}{c}-1.375^{* * *} \\
{[0.428]}\end{array}$ \\
\hline Education & $\begin{array}{c}0.706 \\
{[0.536]}\end{array}$ & $\begin{array}{c}0.577 \\
{[0.478]}\end{array}$ & $\begin{array}{c}0.618 \\
{[0.504]}\end{array}$ & $\begin{array}{l}1.553 * \\
{[0.824]}\end{array}$ \\
\hline CapitalFormation & $\begin{array}{c}6.583^{* * *} \\
{[1.624]}\end{array}$ & $\begin{array}{c}7.148^{* * *} \\
{[1.714]}\end{array}$ & $\begin{array}{c}4.471^{* * *} \\
{[1.145]}\end{array}$ & $\begin{array}{c}6.291 * * * \\
{[1.806]}\end{array}$ \\
\hline FinancialDevelopment & $\begin{array}{c}-1.959 * * \\
{[0.936]}\end{array}$ & $\begin{array}{l}-1.380 \\
{[1.058]}\end{array}$ & $\begin{array}{l}-1.391 \\
{[0.862]}\end{array}$ & $\begin{array}{l}-1.978 \\
{[1.512]}\end{array}$ \\
\hline FinancialOpenness & $\begin{array}{c}0.491 \text { *** } \\
{[0.146]}\end{array}$ & $\begin{array}{c}0.293^{* * *} \\
{[0.102]}\end{array}$ & $\begin{array}{c}0.440 * * * \\
{[0.144]}\end{array}$ & $\begin{array}{l}0.0964 \\
{[0.113]}\end{array}$ \\
\hline TradeOpenness & $\begin{array}{l}-2.609 \\
{[1.779]}\end{array}$ & $\begin{array}{l}-1.969 \\
{[1.551]}\end{array}$ & $\begin{array}{l}-2.116 \\
{[1.688]}\end{array}$ & $\begin{array}{l}-1.998 \\
{[2.012]}\end{array}$ \\
\hline Road & $\begin{array}{l}0.0184 \\
{[0.087]}\end{array}$ & $\begin{array}{l}0.0814 \\
{[0.099]}\end{array}$ & $\begin{array}{l}-0.038 \\
{[0.082]}\end{array}$ & $\begin{array}{l}-0.0302 \\
{[0.140]}\end{array}$ \\
\hline GovernmentSize & $\begin{array}{c}10.42 * * * \\
{[3.584]}\end{array}$ & $\begin{array}{l}9.498^{* *} \\
{[3.487]}\end{array}$ & $\begin{array}{l}8.733^{* *} \\
{[3.422]}\end{array}$ & $\begin{array}{l}23.43^{* *} \\
{[9.236]}\end{array}$ \\
\hline Population & $\begin{array}{c}-14.92^{* * *} \\
{[3.416]}\end{array}$ & $\begin{array}{c}-9.877^{* * *} \\
{[3.005]}\end{array}$ & $\begin{array}{c}-14.14^{* * *} \\
{[2.946]}\end{array}$ & $\begin{array}{c}-18.26^{* * *} \\
{[5.227]}\end{array}$ \\
\hline GDPPerCapita & $\begin{array}{c}-10.410 * * * \\
{[2.241]}\end{array}$ & $\begin{array}{c}-7.110^{* * *} \\
{[2.499]}\end{array}$ & $\begin{array}{c}-7.722^{* * *} \\
{[1.779]}\end{array}$ & $\begin{array}{c}-13.80 * * \\
{[5.154]}\end{array}$ \\
\hline IndustrialStructure & $\begin{array}{c}0.198^{* * *} \\
{[0.071]}\end{array}$ & $\begin{array}{l}0.146 * \\
{[0.072]}\end{array}$ & $\begin{array}{c}0.174^{* * *} \\
{[0.059]}\end{array}$ & $\begin{array}{l}0.00689 \\
{[0.127]}\end{array}$ \\
\hline SolidWasteEmission & $\begin{array}{c}-0.116^{* *} \\
{[0.048]}\end{array}$ & $\begin{array}{c}-0.126^{* *} \\
{[0.054]}\end{array}$ & $\begin{array}{c}-0.0768^{* *} \\
{[0.028]}\end{array}$ & $\begin{array}{c}-0.0622 \\
{[0.073]}\end{array}$ \\
\hline $\begin{array}{l}\text { Province-fixed effect } \\
\text { Time-fixed effect }\end{array}$ & $\begin{array}{l}\text { Yes } \\
\text { Yes }\end{array}$ & $\begin{array}{l}\text { Yes } \\
\text { Yes }\end{array}$ & $\begin{array}{l}\text { Yes } \\
\text { Yes }\end{array}$ & $\begin{array}{l}\text { Yes } \\
\text { Yes }\end{array}$ \\
\hline Observations & 496 & 496 & 496 & 496 \\
\hline Provinces & 31 & 31 & 31 & 31 \\
\hline$R^{2}$ & 0.770 & 0.784 & 0.773 & 0.564 \\
\hline
\end{tabular}

Note: $(1)^{* * *}, * *$, and $*$ represent the significance levels of $1 \%, 5 \%$, and $10 \%$, respectively. Heteroscedasticity-robust standard errors are reported in parentheses. (2) Abbreviation: GDP (gross domestic product), $\mathrm{SO}_{2}$ (sulfur dioxide).

Overall, the robustness checks in columns (ii)-(iv) of Table 2 provide explicit and consistent evidence that air pollution had a significant negative correlation with economic growth in China.

\subsection{Results of Instrumental Variables Estimation}

\subsubsection{Baseline}

We intend to confirm the causal effect of air pollution on economic growth. Therefore, we need to make sure that the estimated coefficient of AirPollution does not merely reflect a correlation between AirPollution and Growth. One important thing is that we should control the influences of potential confounding factors (e.g., capital formation, FDI, level of GDP per capita, and industrial structure) which affect both AirPollution and Growth. We have done this by including a set of important control variables in the regression model.

Although we excluded the influences of those control variables, the previous results of the fixed-effects model may still have suffered from the potential endogeneity issue. As the expansion of economic activities generates air pollutant emissions, there probably exists a 
reverse causality from economic growth to air pollution. For example, the reciprocal interaction between economic growth and air quality has been confirmed in the travel and tourism sector. While air pollution influences tourism, the development of tourism industries reversely affects air quality, because tourist activities consume resources and emit pollutants [118-122]. This results in the endogeneity of the explanatory variable in our regression model and causes a bias in the coefficient estimate. The instrumental variable (IV) estimation is an effective approach to mitigate the endogeneity problem. Credible IVs should meet two conditions: First, the IVs should strongly influence the endogenous explanatory variable. Second, the IVs should not have a direct correlation with the dependent variable, except through their links with the endogenous variable. In our research, three meteorological indicators - the annual average wind speed, vapor pressure, and humidity-are selected as useful IVs. First, the environmental literature has already confirmed that these meteorological conditions largely influence the concentration of pollutants in ambient air. For example, Alifa et al. [123], Calkins et al. [124], Koutrakis et al. [125], and Pearce et al. [126] analyzed the considerable influence of wind speed. Aw and Kleeman [127], Pearce et al. [126], and Seinfeld [128] discussed the significant correlation between vapor pressure and air pollution. He et al. [129], Koutrakis et al. [125], Wang and Ogawa [130], and Wise and Comrie [131] reported that humidity strongly affects air pollution. Second, there is no apparent evidence that economic growth is directly impacted by these meteorological conditions. Thus, both conditions for the selection of reliable IVs are met.

We instrumented AirPollution by the meteorological variables and used the standard IV-2SLS (two-stage least squares) method to estimate Equation (1). (The meteorological data were obtained from the China Meteorological Data Service Center at http:// data.cma.cn/en, accessed on 1 March 2021). The IV estimation result is demonstrated in column (i) of Table 3.

In the first-stage regression, the variables of wind speed and vapor pressure both had negative coefficients, and humidity had a positive coefficient. All three of these coefficients were statistically significant at least at the $10 \%$ level, indicating that the three IVs indeed had a significant influence on air pollution, as suggested by previous environmental research. The associated Cragg-Donald Wald F statistic and Kleibergen-Paap rk Wald F statistic were both significant at the $10 \%$ level, showing that the selected IVs were not "weak IVs". The Hansen J statistic was not statistically significant. The insignificant value of the Hansen J statistic suggests that the regression model was not overidentified. Overall, these statistics demonstrate that the IVs were valid instruments and properly used in the estimation.

In the second-stage regression, the estimated coefficient of AirPollution was -5.818, which was statistically significant at the $5 \%$ level. This shows that air pollution, indeed, had a substantially adverse impact on the economic growth rate after we effectively tackled the endogeneity issue by employing the IV approach. The research hypothesis in this study was, therefore, validated. The number suggests that, holding other factors constant, if air pollution can be abated by $1 \%$, the annual economic growth rate will increase by 0.05818 percentage points. It is notable that the magnitude of the coefficient $(-5.818)$ from the IV estimation was much larger than that $(-2.108)$ from the fixed-effects estimation without addressing the endogeneity issue. The endogeneity test $\chi^{2}$ statistic of 2.892 was significant at the $10 \%$ level, clearly rejecting the null hypothesis that air pollution can be regarded as exogenous. This implies that the endogeneity problem, indeed, existed and that it was necessary to use the IV method to obtain a more reliable estimate for AirPollution. The coefficients of control variables were generally similar to those in Table 2, and not discussed here to save space. 
Table 3. Estimated impact of air pollution on economic growth rate based on instrumental variables estimation.

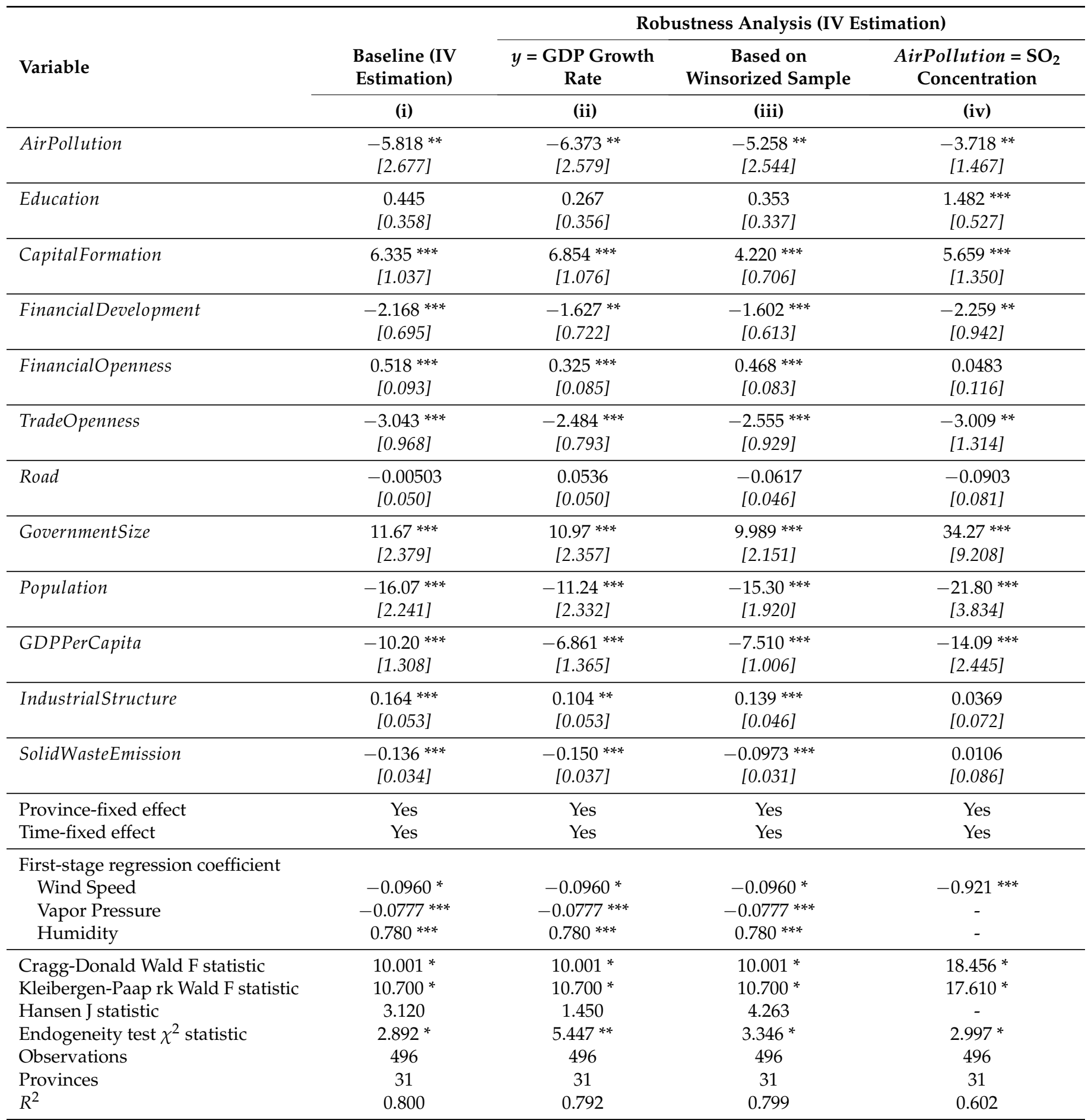

Note: $(1)^{* * *}, * *$, and $*$ represent the significance levels of $1 \%, 5 \%$, and $10 \%$, respectively. Heteroscedasticity-robust standard errors are reported in parentheses. (2) Abbreviations: GDP (gross domestic product), IV (instrumental variable), $\mathrm{SO}_{2}$ (sulfur dioxide). (3) The first-stage regression coefficients, Cragg-Donald Wald F statistic, and Kleibergen-Paap rk Wald F statistic are the same in columns (i)-(iii).

\subsubsection{Robustness Check}

To further verify the IV estimation results, we also conducted several robustness checks, analogous to those in columns (ii)-(iv) of Table 2. In column (ii) of Table 3, we used the GDP growth rate as the dependent variable and repeated the IV estimation procedure. We obtained a coefficient of -6.373 for AirPollution, which was not far from that in column (i). In column (iii), we winsorized the sample at the cutoff point of GDP per capita growth 
rate of top or bottom $2.5 \%$. The estimation using the winsorized sample provided a coefficient of -5.258 for AirPollution, quite close to that in column (i). In column (iv), we used the $\mathrm{SO}_{2}$ concentration as air pollution indicator. In the first-stage regression, we only utilized the wind speed as instrument variable, because vapor pressure and humidity did not demonstrate a significant correlation with $\mathrm{SO}_{2}$ concentration. Accordingly, we did not report the Hansen J statistic because the equation was exactly identified (i.e., the number of instrument variable equals the number of endogenous variable). Using $\mathrm{SO}_{2}$ as the pollution indicator, the estimated coefficient of AirPollution became -3.718, which was also significantly negative.

All in all, the robustness checks for IV estimation in columns (ii)-(iv) of Table 3 all support our previous statement that air pollution impeded economic growth. The magnitudes of the estimated coefficients_- $6.373,-5.258$, and -3.718 - were still much larger than those reported for the fixed-effects model.

\subsection{Heterogeneity Analysis}

The previous analyses have shown an overall adverse influence of air pollution on China's economic growth. However, the impact of air pollution may not be homogeneous during all periods in all regions. In this subsection, we analyze the heterogeneous effects of pollution in different periods and districts. We examine whether the situation differed before and after 2008; before and after 2014; in the eastern, central, and western regions; and in provinces with different shares of state-owned enterprises, different levels of government health expenditures, and different availability of medical resources. The results suggest no evident changes along the time dimension but substantial differences among different regions.

The heterogeneity analysis is based on the following regression model:

$$
\text { Growth }_{i t}=\alpha_{1} \text { AirPollution }_{i t}+\alpha_{2} \text { AirPollution }_{i t} \times D_{i t}+X_{i t} \beta+s_{i}+v_{t}+\varepsilon_{i t},
$$

where $D_{i t}$ is a binary dummy variable that equals 1 or 0 , contingent on some specific conditions which will be defined later. The equation is estimated using the instrumental variables method.

\subsubsection{Before- versus after-2008 Period}

First, we examine whether there was a difference between the before- and after-2008 periods. The global financial crisis in 2008 largely altered the economic structures of many countries. Thus, we conjecture that the effect of air pollution on economic growth might change after the crisis. In order to empirically examine that, we define the dummy variable in Equation (2) as follows: $D_{i t}^{\text {After } 2008}=1$ if $t \geq 2008$, and 0 otherwise. The effects of pollution before and after 2008 are measured by the parameter $\alpha_{1}$ and $\left(\alpha_{1}+\alpha_{2}\right)$, respectively.

Column (i) of Table 4 shows the estimation result. The value of $\alpha_{1}$ was -4.759 and statistically significant. The value of $\alpha_{2}$ was 0.507 , which was small in magnitude compared to the value of $\alpha_{1}$. Moreover, $\alpha_{2}$ was not statistically significant. Therefore, we can conclude that the effects of pollution before and after 2008 were essentially similar.

\subsubsection{Before- versus after-2014 Period}

Next, we check the difference between the before- and after-2014 periods. The year 2013 was a turning point in terms of the public awareness and concern for air pollution in China [132]. On 9 September 2013, the "Air Pollution Prevention and Control Action Plan" was announced by the State Council of China. Then, the whole country implemented stronger policies to deal with the air pollution problem. Therefore, we conjecture that the effects of pollution in periods before and after 2014 may not be the same. We define the dummy variable in Equation (2) as follows: $D_{i t}^{\text {After } 2014}=1$ if $t \geq 2014$, and 0 otherwise.

Column (ii) of Table 4 shows the estimation result. The value of $\alpha_{1}$ was -5.854 , which was statistically significant. The value of $\alpha_{2}$ was -0.0209 , which was quite small 
in magnitude and not statistically significant. Thus, it can be concluded that there was no difference between the before- and after-2014 periods.

Table 4. Heterogeneous effects of air pollution in different periods and regions.

\begin{tabular}{|c|c|c|c|c|c|c|}
\hline \multirow[t]{2}{*}{ Variable } & $\begin{array}{l}\text { Before or After } \\
\quad 2008\end{array}$ & $\begin{array}{l}\text { Before or After } \\
\quad 2014\end{array}$ & $\begin{array}{l}\text { East or Center } \\
\text { and West Region }\end{array}$ & $\begin{array}{l}\text { Smaller or Larger } \\
\text { State-Owned } \\
\text { Enterprises Share }\end{array}$ & $\begin{array}{c}\text { Fewer or More } \\
\text { Governmental } \\
\text { Health Expenditures }\end{array}$ & $\begin{array}{c}\text { Fewer or More } \\
\text { Medical } \\
\text { Resources }\end{array}$ \\
\hline & (i) & (ii) & (iii) & (iv) & (v) & (vi) \\
\hline AirPollution & $\begin{array}{l}-4.759^{*} \\
{[2.620]}\end{array}$ & $\begin{array}{l}-5.854^{* *} \\
{[2.709]}\end{array}$ & $\begin{array}{l}-7.015^{*} \\
{[3.681]}\end{array}$ & $\begin{array}{l}-7.201 * * \\
{[2.987]}\end{array}$ & $\begin{array}{l}-7.408^{* *} \\
{[3.303]}\end{array}$ & $\begin{array}{c}-7.268^{* *} \\
{[2.874]}\end{array}$ \\
\hline $\begin{array}{l}\text { AirPollution } \times \\
D^{\text {After2008 }}\end{array}$ & $\begin{array}{c}0.507 \\
{[0.361]}\end{array}$ & & & & & \\
\hline $\begin{array}{l}\text { AirPollution } \times \\
D^{\text {After2014 }}\end{array}$ & & $\begin{array}{c}-0.0209 \\
{[0.280]}\end{array}$ & & & & \\
\hline $\begin{array}{l}\text { AirPollution } \times \\
D^{\text {Center\&West }}\end{array}$ & & & $\begin{array}{l}5.019 * \\
{[3.040]}\end{array}$ & & & \\
\hline $\begin{array}{l}\text { AirPollution } \times \\
D^{\text {LargerSOEShare }}\end{array}$ & & & & $\begin{array}{l}4.349 * \\
{[2.353]}\end{array}$ & & \\
\hline $\begin{array}{l}\text { AirPollution } \times \\
D^{\text {MoreGovHealthExpend }}\end{array}$ & & & & & $\begin{array}{l}5.898^{* *} \\
{[2.368]}\end{array}$ & \\
\hline $\begin{array}{l}\text { AirPollution } \times \\
D^{\text {MoreMedical Resources }}\end{array}$ & & & & & & $\begin{array}{l}4.591 * \\
{[2.487]}\end{array}$ \\
\hline $\begin{array}{l}\text { Other control } \\
\text { variables }\end{array}$ & Yes & Yes & Yes & Yes & Yes & Yes \\
\hline $\begin{array}{l}\text { Province-fixed } \\
\text { effect }\end{array}$ & Yes & Yes & Yes & Yes & Yes & Yes \\
\hline Time-fixed effect & Yes & Yes & Yes & Yes & Yes & Yes \\
\hline $\begin{array}{l}\text { Observations } \\
\text { Provinces } \\
R^{2}\end{array}$ & $\begin{array}{c}496 \\
31 \\
0.807\end{array}$ & $\begin{array}{c}496 \\
31 \\
0.800\end{array}$ & $\begin{array}{c}496 \\
31 \\
0.809\end{array}$ & $\begin{array}{c}496 \\
31 \\
0.800\end{array}$ & $\begin{array}{c}496 \\
31 \\
0.802\end{array}$ & $\begin{array}{c}496 \\
31 \\
0.801\end{array}$ \\
\hline
\end{tabular}

Note: ${ }^{* *}$ and ${ }^{*}$ represent the significance levels of $5 \%$ and $10 \%$, respectively. Heteroscedasticity-robust standard errors are reported in parentheses. In order to save space, the coefficients of control variables are not reported in the table.

\subsubsection{Eastern versus Central and Western Region}

Thirdly, we classify our sample provinces into two groups according to their geographical locations. The first group contains 11 provinces located in the eastern region. The second group contains 20 provinces located in the central and western regions. The grouping of provinces is based on the official classification of the National Bureau of Statistics of China. As the eastern region of China has significantly higher levels of economic development, urbanization, and population density, compared to the central and western regions, we expect to observe a stronger impact of atmospheric pollution in the eastern region. We define the dummy variable in Equation (2) as follows: $D_{i t}^{\text {Center\&West }}=1$ if the province $i$ is in the central and western regions, and 0 if it is in the eastern region.

Column (iii) of Table 4 reports the estimated coefficients. The value of $\alpha_{1}$ was -7.015 , which was statistically significant. The value of $\alpha_{2}$ was 5.019 , which was also significant. These coefficients imply that there was a substantial difference between the eastern and other regions. If the $\mathrm{PM}_{2.5}$ concentration rises by $1 \%$, the economic growth rate will reduce by 0.07015 percentage points in the eastern region and $0.01996(=0.07015-0.05019)$ percentage points in the central and western regions. Therefore, it is verified that the adverse influence of air pollution on macroeconomic growth is stronger in the eastern region.

\subsubsection{Smaller versus Larger State-Owned Enterprises Share}

Here, we examine whether the share of state-owned enterprises (SOEs) in the economy matters. In China, numerous economic activities are conducted or influenced by SOEs. Compared to non-SOEs, SOEs are generally less efficient and more heavily intervened in 
by governments. Thus, a smaller proportion of SOEs in the economy indicates a larger degree of marketization, resource mobility, and economic vitality. The linkage between air pollution and economic growth may be influenced by the share of SOEs. As the official data sources did not provide information about the aggregate output of SOEs and nonSOEs, we measured the share of SOEs by the ratio of annual investments of SOEs to total investments in the whole province. We define the dummy variable in Equation (2) as follows: $D_{i t}^{\text {LargerSOEShare }}=1$ if the average share of SOEs during the sample period in province $i$ is equal to or above the sample median, and 0 otherwise.

Column (iv) of Table 4 reports the estimated coefficients. The values of $\alpha_{1}$ and $\alpha_{2}$ equaled -7.201 and 4.349 , respectively. Both of them were statistically significant. These coefficients indicate an obvious difference between the regions with different shares of SOEs. In a province with a relatively small SOEs share, a $1 \%$ increase in $\mathrm{PM}_{2.5}$ concentration makes the economic growth rate decline by 0.07201 percentage points. In a province with a relatively large SOEs share, the economic growth rate will reduce by $0.02852(=0.07201-0.04349)$ percentage points. The negative effect of air pollution on economic growth is stronger in the regions with smaller SOEs shares.

\subsubsection{Fewer versus More Governmental Health Expenditures}

The impact of air pollution may not be homogeneous in all regions. As discussed previously, the negative influence of air pollution on economic growth is largely grounded in its harmfulness to human health. Therefore, it is natural to consider that an improvement in public health services may help mitigate the damage of air pollution to economic growth. For instance, suppose that pollution causes a higher incidence of respiratory diseases of laborers. The patients living in provinces with a better public health service system can get better medical treatments and be cured sooner. Thus, in these regions, the loss of labor productivity caused by air-pollution-induced respiratory diseases will be relatively small. Following this logic, we conjecture that the negative impact of air pollution on economic growth is weaker in regions with better public health services.

In China, the government plays a determinant role in the provision of public health services. Hence, we focus on the part of public health services financed by the government. We calculate the scale of public health spending from the fiscal budget as a ratio to total government expenditures. A high ratio indicates that the government spends a large proportion of fiscal budget on public health services, implying a strong willingness to provide good services to the public. Ceteris paribus, we can reasonably believe that the higher the ratio, the better the public health services in the corresponding region. The dummy variable in Equation (2) is defined as follows: $D_{i t}^{\text {MoreGovHealthExpenditures }}=1$ if the average ratio of public health spending to total government spending during the sample period in province $i$ is equal to or above the sample median, and 0 otherwise.

Column (v) of Table 4 reports the estimation result. The values of $\alpha_{1}$ and $\alpha_{2}$ were -7.408 and 5.898 , respectively. Both of them were statistically significant. These coefficients show an evident difference between the regions with different levels of public health services. In a province with the local government spending a small proportion of fiscal spending on public health services, a $1 \%$ rise in $\mathrm{PM}_{2.5}$ concentration causes the economic growth rate to reduce by 0.07408 percentage points. In a province with the government spending a large share of fiscal budget on public health, the economic growth rate will decrease by $0.0151(=0.07408-0.05898)$ percentage points. The negative impact of air pollution on economic growth is severer in the regions with fewer governmental expenditures for public health services.

\subsubsection{Fewer versus More Medical Resources}

Given that the adverse health effect of atmospheric pollution is a major reason of the negative air pollution-economic growth linkage, the availability of medical resources within the region matters. Holding other factors constant, in districts with more medical resources, residents can obtain better healthcare services and, thus, are less damaged by 
air pollution. Accordingly, we conjecture that the inhibitory impact of air pollution on macroeconomic growth is weaker in provinces with more medical resources.

We measure the availability of medical resources using the ratio of the number of beds in healthcare institutions to the local population. A higher ratio indicates more availability of medical resources. The dummy variable in Equation (2) is defined as follows: $D_{i t}^{\text {MoreMedicalResources }}=1$ if the average availability of medical resources during the sample period in province $i$ is equal to or above the sample median, and 0 otherwise.

Column (vi) of Table 4 shows the estimated coefficients. The values of $\alpha_{1}$ and $\alpha_{2}$ equaled -7.268 and 4.591 , respectively. Both coefficients were statistically significant. If $\mathrm{PM}_{2.5}$ pollution increases by $1 \%$, the economic growth rate in areas with fewer medical resources will decrease by 0.07268 percentage points, and that in areas with more medical resources will decrease by $0.02677(=0.07268-0.04591)$ percentage points. An explicit quantitative distinction exists between the regions with a different abundance of medical resources. The inhibitory impact of air pollution is stronger in provinces with fewer healthcare resources.

The heterogeneity analyses discussed above provide three findings. (1) The impact of air pollution on economic growth was always negative. After we classified the samples into different periods and different regions, we observed a negative effect in all subsamples. (2) There is no significant heterogeneity along the time dimension. The estimated impacts of air pollution in before- and after-2008 periods are similar. The estimated impacts in before- and after-2014 periods are also similar. (3) There are some quantitative differences along the geographical dimension. The harmful influence of air pollution is stronger in China's eastern region and in provinces with smaller state-owned enterprises shares, fewer governmental expenditures for public health services, and fewer healthcare resources.

\section{Discussion, Conclusions, and Directions for Future Research}

\subsection{Discussion}

China's economic growth has gradually slowed down in recent years. The blue-solid curve in Figure 3 shows the annual growth rate of the real GDP per capita of China over the past ten years (2010-2019). As can be seen from the graph, an evident decline in economic growth rate has been observed. It is of widespread concern whether and to what extent China can maintain its economic growth miracle in the future. Our study suggests that the air pollution problem poses a substantial threat to the economic growth of China. This finding has a clear policy implication: even from a purely economic perspective, China should implement effective policies to mitigate the atmospheric pollution problem. The aim of promoting economic growth and the desire to have clean air are not contradictory. According to our IV estimation (column (i) of Table 3), if the concentration of $\mathrm{PM}_{2.5}$ can be diminished by $10 \%$-which is not an unrealistic target-the annual growth rate of GDP per capita will be improved by 0.5818 percentage points. This is, indeed, a large benefit. The actions of environmental protection have a substantial positive economic outcome. The orange-dashed curve in Figure 4 displays the estimated growth rate of GDP per capita after an imagined $10 \%$ reduction in air pollution, which is substantially higher than the actual level.

The estimated impact of air pollution on economic growth rate in this study allows us to appraise the accumulative benefits of air pollution abatement in terms of GDP and GDP per capita. For example, let us consider what would happen if China had reduced the concentration of $\mathrm{PM}_{2.5}$ by $10 \%$ since 2010. As already demonstrated in Figure 4, in such a scenario, the annual growth rate of GDP per capita would be 0.5818 percentage points higher than its actual value observed in the data. Therefore, the level of GDP per capita in every year since 2010 would also be higher than the actual level. Figure 5 demonstrates the estimated GDP per capita under the air-pollution-reduction scenario versus the actual level during the period 2010-2019. It is notable from the graph that, as time goes on, the gap between the actual and the estimated levels becomes larger. In 2019, the actual GDP per capita of China was USD 8255 (in constant 2010 price), while the estimated value 
reached USD 8714, which is over 5.6\% larger than the actual level. It is also convenient to calculate the variations of GDP. In 2019, China's actual GDP was around USD 11.5 trillion (in constant 2010 price). If $\mathrm{PM}_{2.5}$ had been reduced by $10 \%$ since 2010, the GDP would have reached the scale of USD 12.1 trillion. The difference of USD $0.6(=12.1-11.5)$ trillion is so large that it is close to the economic scale of Poland or Sweden. The more China abates air pollution, the larger are the benefits, in terms of GDP or GDP per capita, that can be acquired. Moreover, as demonstrated previously in Figure 2, the earlier the country reduces air pollution, the larger is the scale of GDP expansion that can be obtained. In other words, if China can effectively improve its air quality earlier, the benefits will be more substantial.

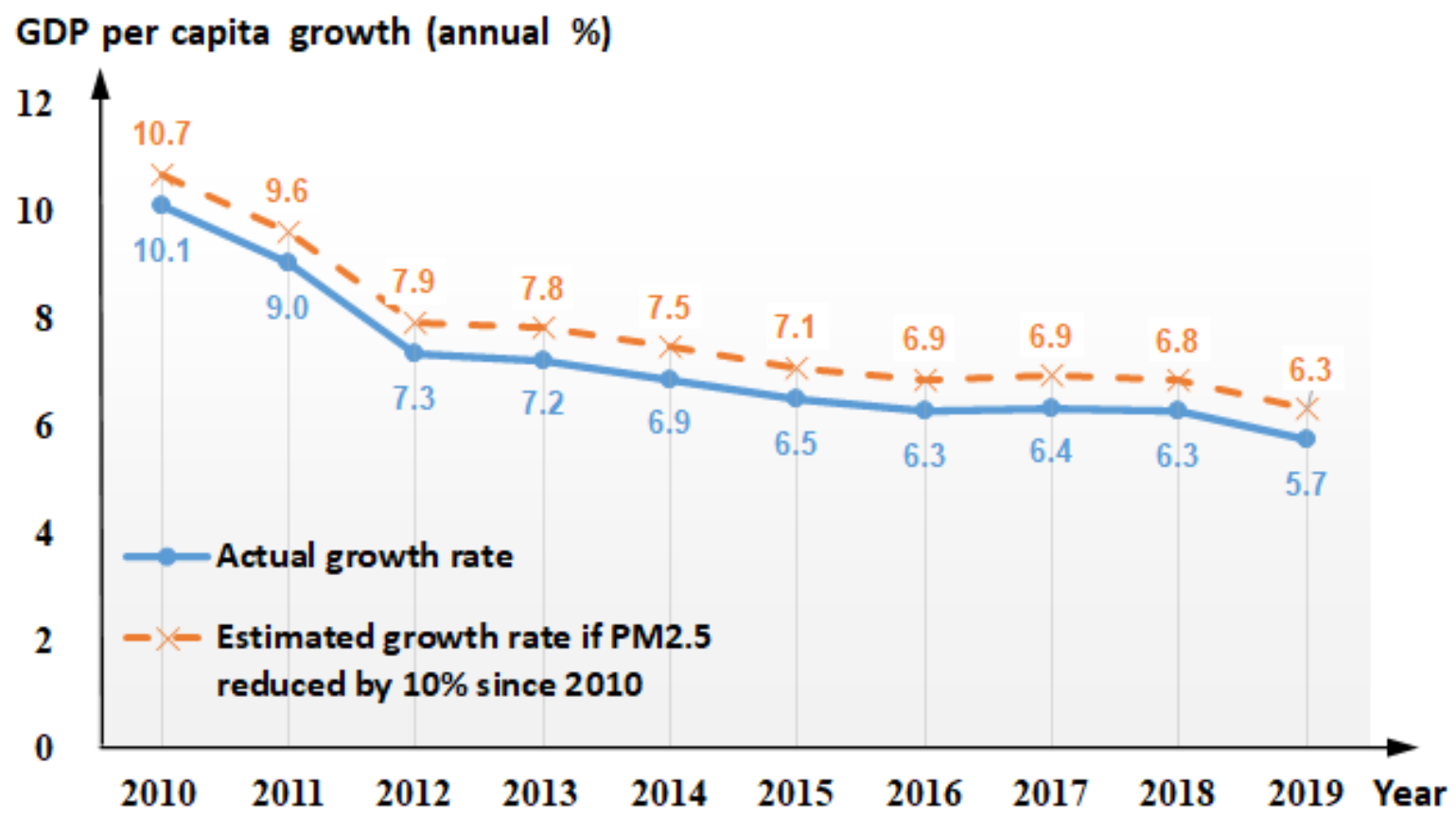

Figure 4. Annual growth rate of GDP per capita of China during 2010-2019. Abbreviation: GDP (gross domestic product). Data source of GDP per capita growth: World Bank's World Development Indicators database.

Prior studies have revealed that several Chinese economic sectors were greatly harmed by poor air quality in direct and indirect ways. A noticeable industry that garnered much attention is that of tourism. Becken et al. [10], Xu and Reed [48,49], and Yang and Chen [50], among others, emphasized the significant negative influences of atmospheric pollution on tourist arrivals and receipts in China. The agricultural losses due to air pollution are also substantial, as reported in the literature. For example, Wei et al. [133] estimated that, during the year of 2008, the damage costs in agriculture caused by industrial $\mathrm{SO}_{2}$ pollution were around $\$ 1.43$ billion, not to mention other kinds of air pollutants. As air pollution causes a great number of socioeconomic costs due to pollution-induced diseases, hospital admissions, mortality, and medical expenditures [134], there are observable reductions in the efficiency and productivity in a range of labor-intensive industries, such as call centers, garment processing, and textiles $[5,135,136]$. Some high-technology industries may also be affected because the accumulation of human capital and the advancement in innovation and $R \& D$ are impeded by pollution [32,137]. 


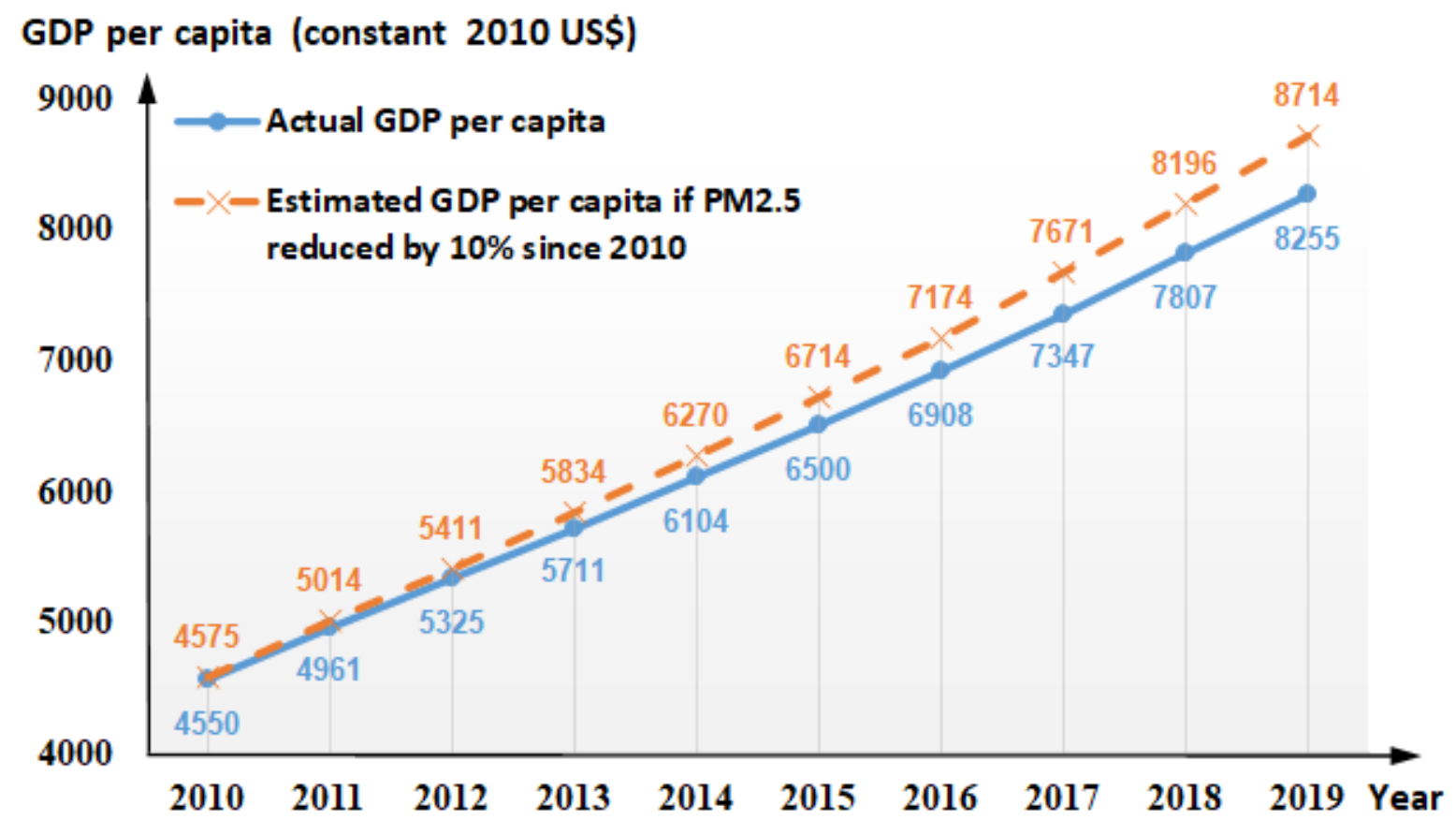

Figure 5. Level of GDP per capita of China during 2010-2019. Abbreviation: GDP (gross domestic product). Data source of GDP per capita: World Bank's World Development Indicators database.

China has undertaken much effort to reduce air pollution in recent years. Many actions, including technological innovation, citizen engagement, and top-down policy initiatives, have been implemented [138]. Chinese residents demonstrated a strong public willingness to pay for air pollution mitigation [139]. Although air pollution has been reduced, the current air quality remains unsatisfactory. According to the data from World Bank's World Development Indicators, in 2017, 99.998\% of the Chinese population was exposed to $\mathrm{PM}_{2.5}$ pollution levels exceeding the World Health Organization (WHO) guideline value (i.e., $10 \mu \mathrm{g} / \mathrm{m}^{3}$ ), and $81.239 \%$ of the population was exposed to levels over the WHO Interim Target-1 value (i.e., $35 \mu \mathrm{g} / \mathrm{m}^{3}$ ). While air pollution is especially serious in China's eastern areas, which have dense population, a high urbanization rate, and intensive economic production, significant pollution levels are also widespread across northern and central China [140-142]. Given the seriousness of the atmospheric pollution problem in China, the country has significant potential to improve its air quality. For instance, the deeper de-carbonization of the energy system will be very helpful [143]. Based on the results of our study, it is expected that, if China is able to reduce its air pollution effectively in the future, a great volume of economic activities can be stimulated and the country's economic development can reach a higher level. This study offers some useful policy implications, which are stated as follows.

First, it is economically beneficial for China to improve air quality as soon as possible. Abating air pollution can increase GDP growth rate and hence bring about large long-term accumulative welfare in terms of the expansion of economic scale. As long as the benefit of pollution abatement is greater than its cost, the government should make long-run plans for industrial structure adjustment and upgrade, implement regulations on high pollution enterprises, and develop environmentally friendly sectors and a circular economy in order to reduce pollution.

Second, different regions should strengthen the cross-regional coordination and take cooperative measures to prevent and control pollution. It is observed that the impact of air pollution on economic growth is always negative across different regions, although some heterogeneities are detected. Therefore, the adverse impact of pollution should be a concern of all Chinese regions. The efforts of a small number of districts are not enough 
to solve the problem in the whole country. The effective mechanism for cross-regional cooperation, such as those already built in the Beijing-Tianjin-Hebei region and the Yangtze River Delta, is indispensable.

Third, stronger policy supports should be provided to the provinces in which the damage of air pollution is severer. For instance, more favorable tax policies, greater public subsidies, and deeper green finance reforms aimed to develop renewable and clean energies and environmental protection industries could be encouraged. The analyses on different subsamples of this study suggest that the influence of atmospheric pollution on regional macroeconomic growth is substantially stronger in the eastern provinces and in provinces where the shares of state-owned enterprises are smaller, the local governments spend a smaller portion of the fiscal budgets on providing public health services, and medical resources are less abundant. The areas with a stronger impact of air pollution should pay more attention and bear more responsibility. Our analyses also indicate that, in order to mitigate the adverse effect of air pollution, the governments should increase the budget of public health service expenditures and provide supports to expand the local medical resources. These actions will not only benefit residents' health but also promote local economic growth. These are important, especially when there are difficulties in improving air quality in the short run.

\subsection{Conclusions and Directions for Future Research}

In summary, this study empirically examined the influence of air pollution on the regional economic growth in Chinese provinces, on the basis of a sample during 2002-2017. The results showed the significant negative impact of air pollution on economic growth, and thus, the research hypothesis in this study was confirmed. It was estimated that the annual growth rate of real GDP per capita declines by 0.05818 percentage points as a result of a $1 \%$ increase in $\mathrm{PM}_{2.5}$ concentration. Therefore, the purpose of promoting economic growth actually requires the government to tackle the air pollution issue. In addition, it is found that the adverse effect of atmospheric pollution is qualitatively consistent but quantitatively heterogeneous across different regions.

This research has several limitations, which provide opportunities for future studies. (1) This research selected China as the target country and conducted an analysis on the basis of a Chinese sample. It is also very important to investigate similar scenarios in some other highly polluted developing countries, such as Bangladesh, India, Mongolia, and Pakistan. Lessons and experience from these countries will definitely be valuable. In future studies, scholars can investigate the influences of air pollution on economic growth in other countries and examine whether our findings based on Chinese data are also applicable to other regions. (2) This research analyzed the influence of air pollution at the province level. Given the fact that China has a vast territory, the different cities and counties may be highly heterogeneous even within one specific province. Thus, the effect of air pollution may not be uniform over a whole province. In the future, researchers can collect more detailed cityor county-level data, in order to provide deeper insights into how regional characteristics mediate the impact of pollution on economic growth. (3) In this study, we considered the regional macroeconomy as a whole without inspecting individual industries and sectors separately. It is possible that air pollution influences the growth of different industries unequally. Future studies could distinguish different industrial sectors to evaluate the impact of pollution. This can provide a more accurate understanding and help us identify the most crucial industries. (4) This study focused on the pollution in air and did not compare the relative importance of different pollution types. Some useful implications might be obtained if diverse pollution categories, such as air pollution, water pollution, solid wastes, and noise, can be included in a more complete model. By utilizing such a model, future researchers can provide a list of priorities to abate different pollutants. (5) The regression model in this study did not consider the possibility of cross-sectional dependence. As air pollution and economic activities might have spatial spillover effects, ignoring cross-sectional dependence possibly results in inaccurate estimates. In the future, 
researchers can construct a more sophisticated model, which incorporates cross-sectional dependence and instrumental variables estimation, to re-examine the impact of pollution.

Author Contributions: Conceptualization, D.D.; data curation, D.D.; formal analysis, D.D.; methodology, D.D.; software, N.S. and Q.H.; supervision, N.S. and Q.H.; validation, N.S. and Q.H.; writingoriginal draft preparation, D.D. and B.X.; writing-review and editing, B.X. All authors have read and agreed to the published version of the manuscript.

Funding: This research received no external funding.

Institutional Review Board Statement: Not applicable.

Informed Consent Statement: Not applicable.

Data Availability Statement: The data used in the current study are available from the corresponding author on request.

Acknowledgments: The authors are grateful to the editors and three anonymous referees for their comments and suggestions.

Conflicts of Interest: The authors declare no conflict of interest.

\section{Abbreviations}

The following abbreviations are used in this manuscript:

$\begin{array}{ll}\mathrm{CNY} & \text { Chinese Yuan } \\ \mathrm{CO}_{2} & \text { Carbon dioxide } \\ \mathrm{GDP} & \text { Gross domestic product } \\ \mathrm{IV} & \text { Instrumental variable } \\ \mathrm{Max} & \text { Maximum } \\ \mathrm{Min} & \text { Minimum } \\ \mathrm{NO}_{2} & \text { Nitrogen dioxide } \\ \mathrm{Obs} & \text { Observations } \\ \mathrm{PM}_{2.5} & \text { Fine particulate matter } \\ \mathrm{SD} & \text { Standard deviation } \\ \mathrm{SO}_{2} & \text { Sulfur dioxide }\end{array}$

\section{References}

1. Amegah, A.K.; Jaakkola, J.J. Household air pollution and the sustainable development goals. Bull. World Health Organ. 2016, 94, 215-221. [CrossRef]

2. Guo, D.; Cao, Z.; DeFrancia, K.; Yeo, J.W.G.; Hardadi, G.; Chai, S. Awareness, perceptions and determinants of urban sustainable development concerns-Evidence from a central province in China. Sustain. Dev. 2018, 26, 652-662. [CrossRef]

3. Rafaj, P.; Kiesewetter, G.; Gül, T.; Schöpp, W.; Cofala, J.; Klimont, Z.; Purohit, P.; Heyes, C.; Amann, M.; Borken-Kleefeld, J.; et al. Outlook for clean air in the context of sustainable development goals. Glob. Environ. Chang. 2018, 53. [CrossRef]

4. Chang, T.; Graff Zivin, J.; Gross, T.; Neidell, M. Particulate Pollution and the Productivity of Pear Packers. Am. Econ. J. Econ. Policy 2016, 8, 141-169. [CrossRef]

5. He, J.; Liu, H.; Salvo, A. Severe Air Pollution and Labor Productivity: Evidence from Industrial Towns in China. Am. Econ. J. Appl. Econ. 2019, 11, 173-201. [CrossRef]

6. Huang, X.; Lanz, B. The Value of Air Quality in Chinese Cities: Evidence from Labor and Property Market Outcomes. Environ. Resour. Econ. 2018, 71, 849-874. [CrossRef]

7. Cole, M.A.; Elliott, R.J.R.; Lindley, J.K. Dirty money: Is there a wage premium for working in a pollution intensive industry? J. Risk Uncertain. 2009, 39, 161-180. [CrossRef]

8. Cui, C.; Wang, Z.; He, P.; Yuan, S.; Niu, B.; Kang, P.; Kang, C. Escaping from pollution: The effect of air quality on inter-city population mobility in China. Environ. Res. Lett. 2019, 14, 124025. [CrossRef]

9. Qin, Y.; Zhu, H. Run away? Air pollution and emigration interests in China. J. Popul. Econ. 2018, 31, 235-266. [CrossRef]

10. Becken, S.; Jin, X.; Zhang, C.; Gao, J. Urban air pollution in China: Destination image and risk perceptions. J. Sustain. Tour. 2017, 25, 130-147. [CrossRef]

11. Xu, B.; Dong, D. Evaluating the Impact of Air Pollution on China's Inbound Tourism: A Gravity Model Approach. Sustainability 2020, 12, 1456. [CrossRef] 
12. Myhre, O.; Låg, M.; Villanger, G.D.; Oftedal, B.; Øvrevik, J.; Holme, J.A.; Aase, H.; Paulsen, R.E.; Bal-Price, A.; Dirven, H. Early life exposure to air pollution particulate matter (PM) as risk factor for attention deficit/hyperactivity disorder (ADHD): Need for novel strategies for mechanisms and causalities. Toxicol. Appl. Pharmacol. 2018, 354, 196-214. [CrossRef] [PubMed]

13. Tzivian, L.; Winkler, A.; Dlugaj, M.; Schikowski, T.; Vossoughi, M.; Fuks, K.; Weinmayr, G.; Hoffmann, B. Effect of long-term outdoor air pollution and noise on cognitive and psychological functions in adults. Int. J. Hyg. Environ. Health $2015,218$. [CrossRef]

14. Khajavi, A.; Khalili, D.; Azizi, F.; Hadaegh, F. Impact of temperature and air pollution on cardiovascular disease and death in Iran: A 15-year follow-up of Tehran Lipid and Glucose Study. Sci. Total Environ. 2019, 661, 243-250. [CrossRef]

15. Chen, J.C.; Schwartz, J. Neurobehavioral effects of ambient air pollution on cognitive performance in US adults. NeuroToxicology 2009, 30, 231-239. [CrossRef] [PubMed]

16. Gatto, N.M.; Henderson, V.W.; Hodis, H.N.; St. John, J.A.; Lurmann, F.; Chen, J.C.; Mack, W.J. Components of air pollution and cognitive function in middle-aged and older adults in Los Angeles. NeuroToxicology 2014, 40, 1-7. [CrossRef] [PubMed]

17. Szyszkowicz, M.; Stieb, D.M.; Rowe, B.H. Air pollution and daily ED visits for migraine and headache in Edmonton, Canada. Am. J. Emerg. Med. 2009, 27, 391-396. [CrossRef]

18. Ghorani-Azam, A.; Riahi-Zanjani, B.; Balali-Mood, M. Effects of air pollution on human health and practical measures for prevention in Iran. J. Res. Med. Sci. 2016, 21, 65. [CrossRef]

19. Szyszkowicz, M.; Kousha, T.; Kingsbury, M.; Colman, I. Air Pollution and Emergency Department Visits for Depression: A Multicity Case-Crossover Study. Environ. Health Insights 2016, 10, 155-161. [CrossRef]

20. Ji, M.; Cohan, D.S.; Bell, M.L. Meta-analysis of the association between short-term exposure to ambient ozone and respiratory hospital admissions. Environ. Res. Lett. 2011, 6, 024006. [CrossRef]

21. Kowalska, M.; Skrzypek, M.; Kowalski, M.; Cyrys, J. Effect of $\mathrm{NOx}$ and $\mathrm{NO}_{2}$ Concentration Increase in Ambient Air to Daily Bronchitis and Asthma Exacerbation, Silesian Voivodeship in Poland. Int. J. Environ. Res. Public Health 2020, 17, 754. [CrossRef]

22. Cohen, A.J.; Brauer, M.; Burnett, R.; Anderson, H.R.; Frostad, J.; Estep, K.; Balakrishnan, K.; Brunekreef, B.; Dandona, L.; Dandona, R.; et al. Estimates and 25-year trends of the global burden of disease attributable to ambient air pollution: An analysis of data from the Global Burden of Diseases Study 2015. Lancet 2017, 389, 1907-1918. [CrossRef]

23. Zhou, M.; Wang, H.; Zeng, X.; Yin, P.; Zhu, J.; Chen, W.; Li, X.; Wang, L.; Wang, L.; Liu, Y.; et al. Mortality, morbidity, and risk factors in China and its provinces, 1990-2017: A systematic analysis for the Global Burden of Disease Study 2017. Lancet 2019, 394, 1145-1158. [CrossRef]

24. Zhao, Q.; Yuan, C.H. Did Haze Pollution Harm the Quality of Economic Development?-An Empirical Study Based on China's $\mathrm{PM}_{2.5}$ Concentrations. Sustainability 2020, 12, 1607. [CrossRef]

25. Atesoglu, H.S.; Smithin, J. Real wages, productivity and economic growth in the G7, 1960-2002. Rev. Political Econ. 2006, 18, 223-233. [CrossRef]

26. Cao, K.H.; Birchenall, J.A. Agricultural productivity, structural change, and economic growth in post-reform China. J. Dev. Econ. 2013, 104, 165-180. [CrossRef]

27. Lee, J.W.; McKibbin, W.J. Service sector productivity and economic growth in Asia. Econ. Model. 2018, 74, 247-263. [CrossRef]

28. Turner, C.; Tamura, R.; Mulholland, S.E. How important are human capital, physical capital and total factor productivity for determining state economic growth in the United States, 1840-2000? J. Econ. Growth 2013, 18, 319-371. [CrossRef]

29. Kim, M.; Yi, O.; Kim, H. The role of differences in individual and community attributes in perceived air quality. Sci. Total Environ. 2012, 425, 20-26. [CrossRef]

30. Pu, S.; Shao, Z.; Fang, M.; Yang, L.; Liu, R.; Bi, J.; Ma, Z. Spatial distribution of the public's risk perception for air pollution: A nationwide study in China. Sci. Total Environ. 2019, 655, 454-462. [CrossRef]

31. Qian, X.; Xu, G.; Li, L.; Shen, Y.; He, T.; Liang, Y.; Yang, Z.; Zhou, W.W.; Xu, J. Knowledge and perceptions of air pollution in Ningbo, China. BMC Public Health 2016, 16, 1138. [CrossRef]

32. Luo, Y.; Yang, J.; Chen, S. Air Pollution, Human Capital Flow and Innovative Vitality-Evidence from Individual Patent Inventions. China Ind. Econ. 2019, 10, 99-117.

33. Ahsan, H.; Haque, M.E. Threshold effects of human capital: Schooling and economic growth. Econ. Lett. 2017, 156, 48-52. [CrossRef]

34. Su, Y.; Liu, Z. The impact of foreign direct investment and human capital on economic growth: Evidence from Chinese cities. China Econ. Rev. 2016, 37, 97-109. [CrossRef]

35. Teixeira, A.A.C.; Queirós, A.S.S. Economic growth, human capital and structural change: A dynamic panel data analysis. Res. Policy 2016, 45, 1636-1648. [CrossRef]

36. Kirillova, K.; Fu, X.; Lehto, X.; Cai, L. What makes a destination beautiful? Dimensions of tourist aesthetic judgment. Tour. Manag. 2014, 42, 282-293. [CrossRef]

37. Łapko, A.; Panasiuk, A.; Strulak-Wójcikiewicz, R.; Landowski, M. The State of Air Pollution as a Factor Determining the Assessment of a City's Tourist Attractiveness-Based on the Opinions of Polish Respondents. Sustainability 2020, $12,1466$. [CrossRef]

38. Łapko, A.; Strulak-Wójcikiewicz, R.; Panasiuk, A. Air quality as a factor affecting urban tourism. Stud. Perieget. 2020, 30, 109-123. [CrossRef] 
39. Salinas Fernández, J.A.; Serdeira Azevedo, P.; Martín Martín, J.M.; Rodríguez Martín, J.A. Determinants of tourism destination competitiveness in the countries most visited by international tourists: Proposal of a synthetic index. Tour. Manag. Perspect. 2020, 33, 100582. [CrossRef]

40. Torres-Delgado, A.; López Palomeque, F. The ISOST index: A tool for studying sustainable tourism. J. Destin. Mark. Manag. 2018, 8, 281-289. [CrossRef]

41. Anaman, K.A.; Looi, C.N. Economic Impact of Haze-Related Air Pollution on the Tourism Industry in Brunei Darussalam. Econ. Anal. Policy 2000, 30, 133-143. [CrossRef]

42. Pulido-Fernández, J.I.; Rodríguez-Díaz, B. Reinterpreting the World Economic Forum's global tourism competitiveness index. Tour. Manag. Perspect. 2016, 20, 131-140. [CrossRef]

43. Rodríguez-Díaz, B.; Pulido-Fernández, J.I. Sustainability as a Key Factor in Tourism Competitiveness: A Global Analysis. Sustainability 2020, 12, 51. [CrossRef]

44. Usman, O.; Bekun, F.V.; Ike, G.N. Democracy and tourism demand in European countries: Does environmental performance matter? Environ. Sci. Pollut. Res. 2020, 27, 38353-38359. [CrossRef] [PubMed]

45. Robaina, M.; Madaleno, M.; Silva, S.; Eusébio, C.; Carneiro, M.J.; Gama, C.; Oliveira, K.; Russo, M.A.; Monteiro, A. The relationship between tourism and air quality in five European countries. Econ. Anal. Policy 2020, 67, 261-272. [CrossRef]

46. Xu, X.; Dong, D.; Wang, Y.; Wang, S. The Impacts of Different Air Pollutants on Domestic and Inbound Tourism in China. Int. J. Environ. Res. Public Health 2019, 16, 5127. [CrossRef] [PubMed]

47. Law, R.; Cheung, C. Air Quality in Hong Kong: A Study of the Perception of International Visitors. J. Sustain. Tour. 2007, 15, 390-401. [CrossRef]

48. Xu, X.; Reed, M. Perceived pollution and inbound tourism in China. Tour. Manag. Perspect. 2017, 21, 109-112. [CrossRef]

49. Xu, X.; Reed, M. Perceived pollution and inbound tourism for Shanghai: A panel VAR approach. Curr. Issues Tour. 2019, 22, 601-614. [CrossRef]

50. Yang, Y.; Chen, G. In search of fresher air: The influence of relative air quality on vacationers' perceptions of destinations' restorative qualities. Int. J. Tour. Res. 2021, 23, 504-516. [CrossRef]

51. Brida, J.G.; Cortes-Jimenez, I.; Pulina, M. Has the tourism-led growth hypothesis been validated? A literature review. Curr. Issues Tour. 2016, 19, 394-430. [CrossRef]

52. Li, K.X.; Jin, M.; Shi, W. Tourism as an important impetus to promoting economic growth: A critical review. Tour. Manag. Perspect. 2018, 26, 135-142. [CrossRef]

53. Agrawal, M.; Singh, B.; Rajput, M.; Marshall, F.; Bell, J.N.B. Effect of air pollution on peri-urban agriculture: A case study. Environ. Pollut. 2003, 126, 323-329. [CrossRef]

54. Bell, J.N.B.; Power, S.A.; Jarraud, N.; Agrawal, M.; Davies, C. The effects of air pollution on urban ecosystems and agriculture. Int. J. Sustain. Dev. World Ecol. 2011, 18, 226-235. [CrossRef]

55. Gu, Y.; Wong, T.W.; Law, C.K.; Dong, G.H.; Ho, K.F.; Yang, Y.; Yim, S.H.L. Impacts of sectoral emissions in China and the implications: Air quality, public health, crop production, and economic costs. Environ. Res. Lett. 2018, 13, 084008. [CrossRef]

56. Atici, C. Carbon emissions in Central and Eastern Europe: Environmental Kuznets curve and implications for sustainable development. Sustain. Dev. 2009, 17, 155-160. [CrossRef]

57. Dinda, S. Environmental Kuznets Curve Hypothesis: A Survey. Ecol. Econ. 2004, 49, 431-455. [CrossRef]

58. Dong, K.; Sun, R.; Dong, C.; Li, H.; Zeng, X.; Ni, G. Environmental Kuznets curve for PM . $_{25}$ emissions in Beijing, China: What role can natural gas consumption play? Ecol. Indic. 2018, 93, 591-601. [CrossRef]

59. Farhani, S.; Mrizak, S.; Chaibi, A.; Rault, C. The environmental Kuznets curve and sustainability: A panel data analysis. Energy Policy 2014, 71, 189-198. [CrossRef]

60. Gokmenoglu, K.K.; Taspinar, N.; Kaakeh, M. Agriculture-induced environmental Kuznets curve: The case of China. Environ. Sci. Pollut. Res. 2019, 26, 37137-37151. [CrossRef] [PubMed]

61. Luo, Y.; Chen, H.; Zhu, Q.; Peng, C.; Yang, G.; Yang, Y.; Zhang, Y. Relationship between Air Pollutants and Economic Development of the Provincial Capital Cities in China during the Past Decade. PLoS ONE 2014, 9, e104013. [CrossRef]

62. Millimet, D.L.; List, J.A.; Stengos, T. The Environmental Kuznets Curve: Real Progress or Misspecified Models? Rev. Econ. Stat. 2003, 85, 1038-1047. [CrossRef]

63. Zhang, J.; Zhang, K.; Zhao, F. Spatial effects of economic growth, energy consumption and environmental pollution in the provinces of China-An empirical study of a spatial econometrics model. Sustain. Dev. 2020, 28, 868-879. [CrossRef]

64. Abdouli, M.; Hammami, S. The Impact of FDI Inflows and Environmental Quality on Economic Growth: An Empirical Study for the MENA Countries. J. Knowl. Econ. 2017, 8, 254-278. [CrossRef]

65. Omri, A.; Nguyen, D.K.; Rault, C. Causal interactions between $\mathrm{CO}_{2}$ emissions, FDI, and economic growth: Evidence from dynamic simultaneous-equation models. Econ. Model. 2014, 42, 382-389. [CrossRef]

66. Omri, A.; Daly, S.; Rault, C.; Chaibi, A. Financial development, environmental quality, trade and economic growth: What causes what in MENA countries. Energy Econ. 2015, 48, 242-252. [CrossRef]

67. Ghosh, S. Examining carbon emissions economic growth nexus for India: A multivariate cointegration approach. Energy Policy 2010, 38, 3008-3014. [CrossRef]

68. Ozturk, I.; Acaravci, A. $\mathrm{CO}_{2}$ emissions, energy consumption and economic growth in Turkey. Renew. Sustain. Energy Rev. 2010, 14, 3220-3225. [CrossRef] 
69. Zhang, X.P.; Cheng, X.M. Energy consumption, carbon emissions, and economic growth in China. Ecol. Econ. 2009, 68, 2706-2712. [CrossRef]

70. Azam, M.; Khan, A.Q.; Abdullah, H.B.; Qureshi, M.E. The impact of $\mathrm{CO}_{2}$ emissions on economic growth: Evidence from selected higher $\mathrm{CO}_{2}$ emissions economies. Environ. Sci. Pollut. Res. 2016, 23, 6376-6389. [CrossRef] [PubMed]

71. Ahmad, N.; Du, L. Effects of energy production and $\mathrm{CO}_{2}$ emissions on economic growth in Iran: ARDL approach. Energy 2017, 123, 521-537. [CrossRef]

72. Muhammad, B. Energy consumption, $\mathrm{CO}_{2}$ emissions and economic growth in developed, emerging and Middle East and North Africa countries. Energy 2019, 179, 232-245. [CrossRef]

73. Dechezleprêtre, A.; Rivers, N.; Stadler, B. The economic cost of air pollution: Evidence from Europe. In OECD Economics Department Working Papers, No. 1584; 2019, OECD Economics Department, Paris, Franc . [CrossRef]

74. Sinha, A. Trilateral association between $\mathrm{SO}_{2} / \mathrm{NO}_{2}$ emission, inequality in energy intensity, and economic growth: A case of Indian cities. Atmos. Pollut. Res. 2016, 7, 647-658. [CrossRef]

75. Hao, Y.; Peng, H.; Temulun, T.; Liu, L.Q.; Mao, J.; Lu, Z.N.; Chen, H. How harmful is air pollution to economic development? New evidence from $\mathrm{PM}_{2.5}$ concentrations of Chinese cities. J. Clean. Prod. 2018, 172, 743-757. [CrossRef]

76. Zhao, D.; Sing, T.F. Air pollution, economic spillovers, and urban growth in China. Ann. Reg. Sci. 2017, 58, 321-340. [CrossRef]

77. Gan, T.; Yang, H.; Liang, W. How do urban haze pollution and economic development affect each other? Empirical evidence from 287 Chinese cities during 2000-2016. Sustain. Cities Soc. 2021, 65, 102642. [CrossRef]

78. Jiang, S.; Wang, J.; Shi, L.; Ma, Z. Impact of Energy Consumption and Air Pollution on Economic Growth-An Empirical Study Based on Dynamic Spatial Durbin Model. Energy Procedia 2019, 158, 4011-4016. [CrossRef]

79. Alesina, A.; Özler, S.; Roubini, N.; Swagel, P. Political instability and economic growth. J. Econ. Growth 1996, 1, $189-211$. [CrossRef]

80. Chikalipah, S.; Makina, D. Economic growth and human development: Evidence from Zambia. Sustain. Dev. 2019, 27, 1023-1033. [CrossRef]

81. Davis, L.; Hopkins, M. The Institutional Foundations of Inequality and Growth. J. Dev. Stud. 2011, 47, 977-997. [CrossRef]

82. Feeny, S.; Iamsiraroj, S.; McGillivray, M. Remittances and Economic Growth: Larger Impacts in Smaller Countries? J. Dev. Stud. 2014, 50, 1055-1066. [CrossRef]

83. Hermes, N.; Lensink, R. Foreign direct investment, financial development and economic growth. J. Dev. Stud. 2003, 40, 142-163. [CrossRef]

84. Njikam, O. Financial liberalization and growth in African economies: The role of policy complementarities. Rev. Dev. Financ. 2017, 7, 73-83. [CrossRef]

85. Rioja, F.; Valev, N. Does one size fit all?: A reexamination of the finance and growth relationship. J. Dev. Econ. 2004, 74, 429-447. [CrossRef]

86. Jin, Y.; Andersson, H.; Zhang, S. Air Pollution Control Policies in China: A Retrospective and Prospects. Int. J. Environ. Res. Public Health 2016, 13, 1219. [CrossRef]

87. Zeng, Y.; Cao, Y.; Qiao, X.; Seyler, B.C.; Tang, Y. Air pollution reduction in China: Recent success but great challenge for the future. Sci. Total Environ. 2019, 663, 329-337. [CrossRef] [PubMed]

88. Fleisher, B.; Li, H.; Zhao, M.Q. Human capital, economic growth, and regional inequality in China. J. Dev. Econ. 2010, 92, 215-231. [CrossRef]

89. Glewwe, P.; Maïga, E.; Zheng, H. The Contribution of Education to Economic Growth: A Review of the Evidence, with Special Attention and an Application to Sub-Saharan Africa. World Dev. 2014, 59, 379-393. [CrossRef]

90. Han, J.S.; Lee, J.W. Demographic change, human capital, and economic growth in Korea. Jpn. World Econ. 2020, 53, 100984. [CrossRef]

91. Li, Y.; Wang, X.; Westlund, H.; Liu, Y. Physical Capital, Human Capital, and Social Capital: The Changing Roles in China's Economic Growth. Growth Chang. 2015, 46, 133-149. [CrossRef]

92. Adams, S. Foreign Direct investment, domestic investment, and economic growth in Sub-Saharan Africa. J. Policy Model. 2009, 31, 939-949. [CrossRef]

93. Bal, D.P.; Dash, D.P.; Subhasish, B. The Effects of Capital Formation on Economic Growth in India: Evidence from ARDL-bound Testing Approach. Glob. Bus. Rev. 2016, 17, 1388-1400. [CrossRef]

94. Uneze, E. The relation between capital formation and economic growth: Evidence from sub-Saharan African countries. J. Econ Policy Reform 2013, 16, 272-286. [CrossRef]

95. Adu, G.; Marbuah, G.; Mensah, J.T. Financial development and economic growth in Ghana: Does the measure of financial development matter? Rev. Dev. Financ. 2013, 3, 192-203. [CrossRef]

96. Arcand, J.L.; Berkes, E.; Panizza, U. Too much finance? J. Econ. Growth 2015, 20, 105-148. [CrossRef]

97. Hassan, M.K.; Sanchez, B.; Yu, J.S. Financial development and economic growth: New evidence from panel data. Q. Rev. Econ. Financ. 2011, 51, 88-104. [CrossRef]

98. Kim, D.H.; Lin, S.C.; Suen, Y.B. Dynamic Effects of Financial Openness on Economic Growth and Macroeconomic Uncertainty. Emerg. Mark. Financ. Trade 2012, 48, 25-54. [CrossRef]

99. Almfraji, M.A.; Almsafir, M.K. Foreign Direct Investment and Economic Growth Literature Review from 1994 to 2012 . Procedia Soc. Behav. Sci. 2014, 129, 206-213. [CrossRef] 
100. Huchet-Bourdon, M.; Le Mouël, C.; Vijil, M. The relationship between trade openness and economic growth: Some new insights on the openness measurement issue. World Econ. 2018, 41, 59-76. [CrossRef]

101. Keho, Y. The impact of trade openness on economic growth: The case of Cote d'Ivoire. Cogent Econ. Financ. 2017, 5, 1332820. [CrossRef]

102. Yanikkaya, H. Trade openness and economic growth: A cross-country empirical investigation. J. Dev. Econ. 2003, 72, 57-89. [CrossRef]

103. Zahonogo, P. Trade and economic growth in developing countries: Evidence from sub-Saharan Africa. J. Afr. Trade 2016, 3, 41-56. [CrossRef]

104. Canning, D.; Pedroni, P. Infrastructure, Long-Run Economic Growth and Causality Tests For Cointegrated PanelsI. Manch. Sch. 2008, 76, 504-527. [CrossRef]

105. Hong, J.; Chu, Z.; Wang, Q. Transport infrastructure and regional economic growth: Evidence from China. Transportation 2011, 38, 737-752. [CrossRef]

106. Kodongo, O.; Ojah, K. Does infrastructure really explain economic growth in Sub-Saharan Africa? Rev. Dev. Financ. 2016, 6, 105-125. [CrossRef]

107. Pradhan, R.P. Investigating the causal relationship between transportation infrastructure, financial penetration and economic growth in G-20 countries. Res. Transp. Econ. 2019, 78, 100766. [CrossRef]

108. Nyasha, S.; Odhiambo, N.M. Government Size and Economic Growth: A Review of International Literature. SAGE Open 2019, 9. [CrossRef]

109. Afonso, A.; Furceri, D. Government size, composition, volatility and economic growth. Eur. J. Political Econ. 2010, 26, 517-532. [CrossRef]

110. DiPeitro, W.R.; Anoruo, E. Government size, public debt and real economic growth: A panel analysis. J. Econ. Stud. 2012, 39, 410-419. [CrossRef]

111. Asimakopoulos, S.; Karavias, Y. The impact of government size on economic growth: A threshold analysis. Econ. Lett. 2016, 139, 65-68. [CrossRef]

112. Chiou-Wei, S.Z.; Zhu, Z.; Kuo, Y.H. Government size and economic growth: An application of the smooth transition regression model. Appl. Econ. Lett. 2010, 17, 1405-1415. [CrossRef]

113. Ahmed, R.N.; Ahmad, K. Impact of Population on Economic Growth: A Case Study of Pakistan. Bull. Bus. Econ. 2016, 5, 162-176.

114. Bucci, A. Population in Factor Accumulation-based Growth. Riv. Ital. Degli Econ. 2010, 33-68. [CrossRef]

115. Van Donkelaar, A.; Martin Randall, V.; Brauer, M.; Boys Brian, L. Use of Satellite Observations for Long-Term Exposure Assessment of Global Concentrations of Fine Particulate Matter. Environ. Health Perspect. 2015, 123, 135-143. [CrossRef] [PubMed]

116. Van Donkelaar, A.; Martin, R.V.; Li, C.; Burnett, R.T. Regional Estimates of Chemical Composition of Fine Particulate Matter Using a Combined Geoscience-Statistical Method with Information from Satellites, Models, and Monitors. Environ. Sci. Technol. 2019, 53, 2595-2611. [CrossRef] [PubMed]

117. Hammer, M.S.; van Donkelaar, A.; Li, C.; Lyapustin, A.; Sayer, A.M.; Hsu, N.C.; Levy, R.C.; Garay, M.J.; Kalashnikova, O.V.; Kahn, R.A.; et al. Global Estimates and Long-Term Trends of Fine Particulate Matter Concentrations (1998-2018). Environ. Sci. Technol. 2020, 54, 7879-7890. [CrossRef]

118. Belsoy, J.; Korir, J.; Yego, J. Environmental Impacts of Tourism in Protected Areas. J. Environ. Earth Sci. 2012, 2, 64-73.

119. Danish.; Wang, Z. Dynamic relationship between tourism, economic growth, and environmental quality. J. Sustain. Tour. 2018, 26, 1928-1943. [CrossRef]

120. Sáenz-de Miera, O.; Rosselló, J. Tropospheric ozone, air pollution and tourism: A case study of Mallorca. J. Sustain. Tour. 2013, 21, 1232-1243. [CrossRef]

121. Sáenz-de Miera, O.; Rosselló, J. Modeling tourism impacts on air pollution: The case study of PM10 in Mallorca. Tour. Manag. 2014, 40, 273-281. [CrossRef]

122. Zhang, N.; Ren, R.; Zhang, Q.; Zhang, T. Air pollution and tourism development: An interplay. Ann. Tour. Res. 2020, 85, 103032. [CrossRef]

123. Alifa, M.; Bolster, D.; Mead, M.I.; Latif, M.T.; Crippa, P. The influence of meteorology and emissions on the spatio-temporal variability of PM10 in Malaysia. Atmos. Res. 2020, 246, 105107. [CrossRef]

124. Calkins, C.; Ge, C.; Wang, J.; Anderson, M.; Yang, K. Effects of meteorological conditions on sulfur dioxide air pollution in the North China plain during winters of 2006-2015. Atmos. Environ. 2016, 147, 296-309. [CrossRef]

125. Koutrakis, P.; Sax, S.N.; Sarnat, J.A.; Coull, B.; Demokritou, P.; Demokritou, P.; Oyola, P.; Garcia, J.; Gramsch, E. Analysis of PM10, $\mathrm{PM}_{2.5}$, and $\mathrm{PM}_{2.5}-10$ Concentrations in Santiago, Chile, from 1989 to 2001. J. Air Waste Manag. Assoc. 2005, 55, 342-351. [CrossRef] [PubMed]

126. Pearce, J.L.; Beringer, J.; Nicholls, N.; Hyndman, R.J.; Tapper, N.J. Quantifying the influence of local meteorology on air quality using generalized additive models. Atmos. Environ. 2011, 45, 1328-1336. [CrossRef]

127. Aw, J.; Kleeman, M.J. Evaluating the first-order effect of intraannual temperature variability on urban air pollution. J. Geophys. Res. Atmos. 2003, 108. [CrossRef]

128. Seinfeld, J.H. Air pollution: A half century of progress. AIChE J. 2004, 50, 1096-1108. [CrossRef] 
129. He, J.; Gong, S.; Yu, Y.; Yu, L.; Wu, L.; Mao, H.; Song, C.; Zhao, S.; Liu, H.; Li, X.; Li, R. Air pollution characteristics and their relation to meteorological conditions during 2014-2015 in major Chinese cities. Environ. Pollut. 2017, 223, 484-496. [CrossRef]

130. Wang, J.; Ogawa, S. Effects of Meteorological Conditions on $\mathrm{PM}_{2.5}$ Concentrations in Nagasaki, Japan. Int. J. Environ. Res. Public Health 2015, 12, 9089-9101. [CrossRef]

131. Wise, E.K.; Comrie, A.C. Meteorologically adjusted urban air quality trends in the Southwestern United States. Atmos. Environ. 2005, 39, 2969-2980. [CrossRef]

132. Lu, Y.; Wang, Y.; Zuo, J.; Jiang, H.; Huang, D.; Rameezdeen, R. Characteristics of public concern on haze in China and its relationship with air quality in urban areas. Sci. Total Environ. 2018, 637-638, 1597-1606. [CrossRef]

133. Wei, J.; Guo, X.; Marinova, D.; Fan, J. Industrial $\mathrm{SO}_{2}$ pollution and agricultural losses in China: Evidence from heavy air polluters. J. Clean. Prod. 2014, 64, 404-413. [CrossRef]

134. Xia, Y.; Guan, D.; Jiang, X.; Peng, L.; Schroeder, H.; Zhang, Q. Assessment of socioeconomic costs to China's air pollution. Atmos. Environ. 2016, 139, 147-156. [CrossRef]

135. Chang, T.Y.; Graff Zivin, J.; Gross, T.; Neidell, M. The Effect of Pollution on Worker Productivity: Evidence from Call Center Workers in China. Am. Econ. J. Appl. Econ. 2019, 11, 151-172. [CrossRef]

136. Chen, S.; Zhang, D. Impact of air pollution on labor productivity: Evidence from prison factory data. China Econ. Q. Int. 2021, 1, 148-159. [CrossRef]

137. Liu, P.; Dong, D.; Wang, Z. The impact of air pollution on R\&D input and output in China. Sci. Total Environ. 2021, 752, 141313. [CrossRef] [PubMed]

138. Tilt, B. China's air pollution crisis: Science and policy perspectives. Environ. Sci. Policy 2019, 92, 275-280. [CrossRef]

139. Dong, K.; Zeng, X. Public willingness to pay for urban smog mitigation and its determinants: A case study of Beijing, China. Atmos. Environ. 2018, 173, 355-363. [CrossRef]

140. Aunan, K.; Hansen, M.H.; Wang, S. Introduction: Air Pollution in China. China Q. 2018, 234, 279-298. [CrossRef]

141. Fan, Y.; Ding, X.; Hang, J.; Ge, J. Characteristics of urban air pollution in different regions of China between 2015 and 2019. Build. Environ. 2020, 180, 107048. [CrossRef]

142. Rohde, R.A.; Muller, R.A. Air Pollution in China: Mapping of Concentrations and Sources. PLoS ONE 2015, 10, e0135749. [CrossRef] [PubMed]

143. Lu, X.; Zhang, S.; Xing, J.; Wang, Y.; Chen, W.; Ding, D.; Wu, Y.; Wang, S.; Duan, L.; Hao, J. Progress of Air Pollution Control in China and Its Challenges and Opportunities in the Ecological Civilization Era. Engineering 2020, 6, 1423-1431. [CrossRef] 